Energy Policies, Forests and Local Communities in the Ucayali Region, Peruvian Amazon

Rodrigo Arce and Roberto Porro

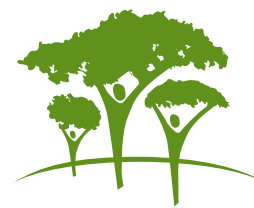





\section{Energy Policies, Forests and Local Communities in the Ucayali Region, Peruvian Amazon}




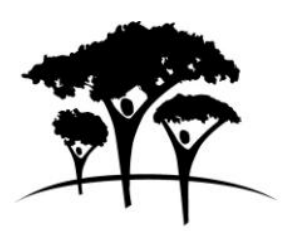

World Agroforestry Centre

TRANSFORMING LIVES AND LANDSCAPES

Correct citation: Arce R and Porro R. 2010. Energy Policies, Forests and Local Communities in the Ucayali Region, Peruvian Amazon. ICRAF Working Paper no. 117. Nairobi, Kenya: World Agroforestry Centre.

Titles in the Working Paper Series aim to disseminate interim results on agroforestry research and practices and stimulate feedback from the scientific community. Other publication series from the World Agroforestry Centre include: Technical Manuals, Occasional Papers and Trees for Change.

Published by the World Agroforestry Centre

United Nations Avenue

PO Box 30677, GPO 00100

Nairobi, Kenya

Tel: +254(0)20 7224000, via USA +1 6508336645

Fax: +254(0)20 7224001, via USA +1 6508336646

Email: icraf@cgiar.org

www.worldagroforestry.org

(C) World Agroforestry Centre 2010

ICRAF Working Paper no. 117

The views expressed in this publication are those of the author(s) and not necessarily those of the World Agroforestry Centre.

Articles appearing in this publication may be quoted or reproduced without charge, provided the source is acknowledged. No use of this publication may be made for resale or other commercial purposes.

The geographic designation employed and the presentation of material in this publication do not imply the expression of any opinion whatsoever on the part of the World Agroforestry Centre concerning the legal status of any country, territory, city or area or its authorities, or concerning the delimitation of its frontiers or boundaries. 


\section{Contributors}

\section{Rodrigo Arce}

Rodrigo Arce is a Forestry Engineer and Mg. Sc in Forest Resource Conservation (Universidad Nacional Agraria La Molina - Peru). He is a well known Peruvian forestry professional and has built a reputation for his socio-cultural approach in community forest management, agroforestry, participatory conservation and climate change.

As a facilitator of social and environmental processes, Rodrigo has contributed to the facilitation of social processes, where assertive communication and generative dialogue play a key role in building sustainable agreements. In this context, he has participated in national processes for public environmental and forestry policy formulation and supported indigenous organizations in exercising their rights. He often publishes essays on environmental, forestry and facilitation issues, and has published five books in this field.

He currently coordinates the project "Promoting the rights of indigenous peoples in the management of natural resources in the Amazon in Bolivia, Ecuador and Peru" at CARE, Peru.

\section{Roberto Porro}

Roberto Porro is an agronomist who holds a $\mathrm{PhD}$ in Cultural Anthropology from the University of Florida. Roberto has built a reputation in the human dimensions of sustainable land use in the Amazon Region. His current research activities focus on how forestry, agroforestry and agricultural activities can contribute to the livelihoods of the Amazonian communities as well as collective action towards environmental conservation. Roberto joined the World Agroforestry Centre in 2003. He is the Regional Coordinator for Latin America Programme and ICRAF's focal point in the Amazon Initiative. His affiliation with the Amazon Initiative Consortium allows for strong partnerships among researchers and stakeholders which is guiding the Centre's research activities in Latin America.

\section{Abstract}

This study analyzes processes and policies of energy development in the Ucayali Region of Peru, and particularly their impacts on local communities. Peru's sustainable development calls for energy policies that respect native communities' rights. However, within the Peruvian modernization process, a clear priority exists to favor private investments over indigenous peoples' rights. Rather than an energy policy focused on sustainable development, the regional political agenda for energy development is closely oriented to increasing energy and excess revenues generated from hydrocarbon exploration and development within the regional territory. Oil exploration blocks are overlaid on native communities' territories and protected areas. The State remains firm in controlling the subsoil and in asserting its power to grant rights to the use of non-renewable natural resources. There is an overwhelming claim by communities on enhancing consultation and participatory mechanisms. Their perception is that greater emphasis has been placed on extracting information and conducting consultations to endorse concessions rather than seeking for consent or social license prior to the granting of oil or gas concessions. Community participation and social control mechanisms must be fostered in order to ensure that the implementation of non-renewable resources' exploration and development activities is carried out with proper management and safeguarding Amazon's essential ecologic processes. 


\section{Contents}

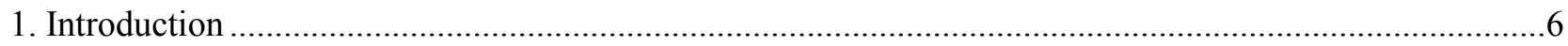

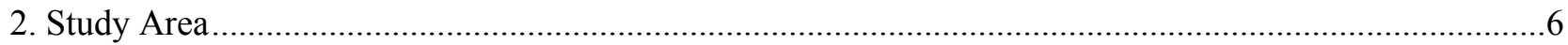

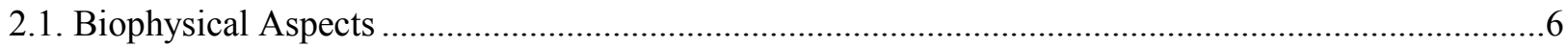

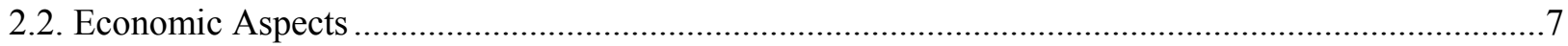

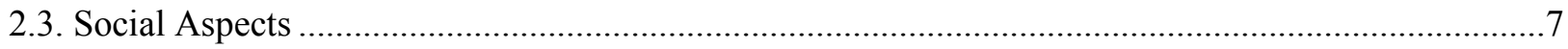

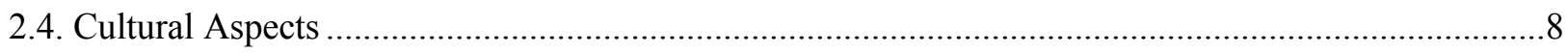

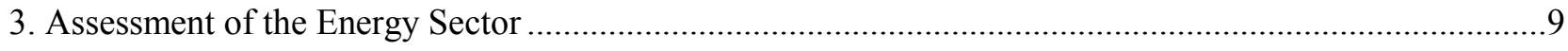

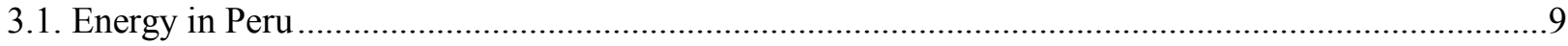

3.2. Domestic Energy Production by Economic Sectors ......................................................................10

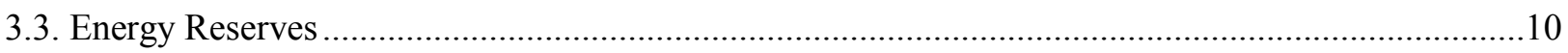

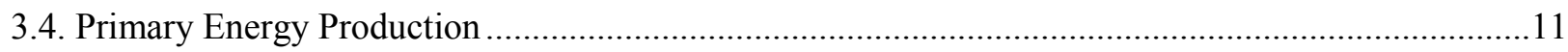

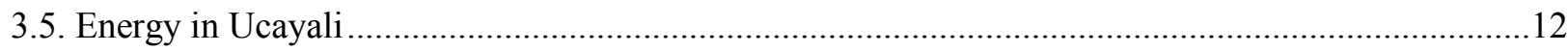

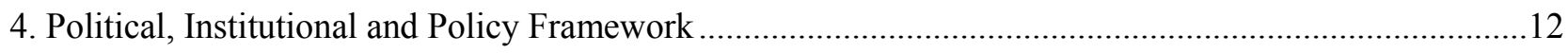

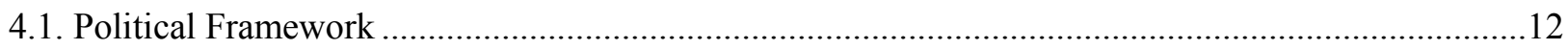

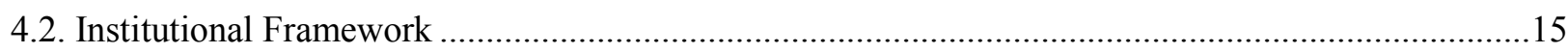

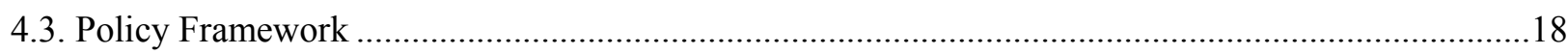

5. Environmental Impacts of Energy Projects in the Ucayali Region ........................................................19

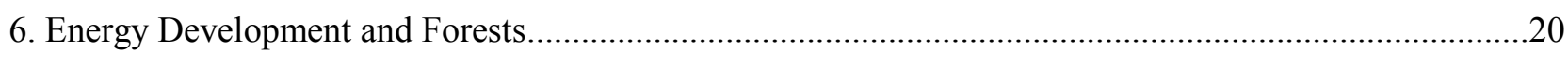

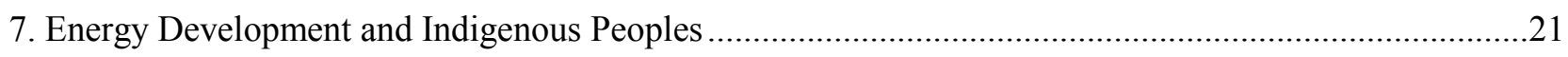

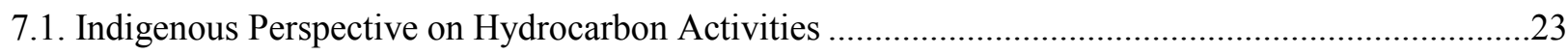

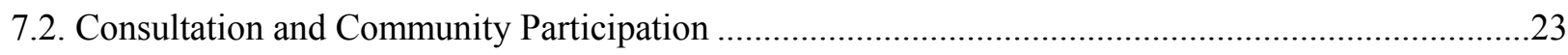

7.3. Energy Development and Indigenous Peoples in Voluntary Isolation.............................................25

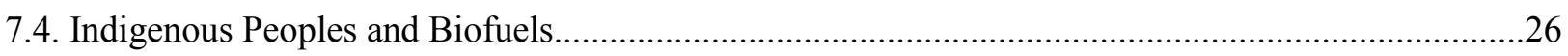

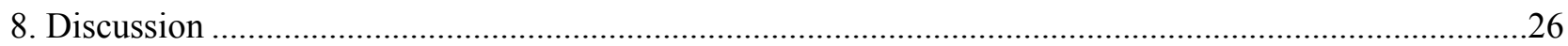

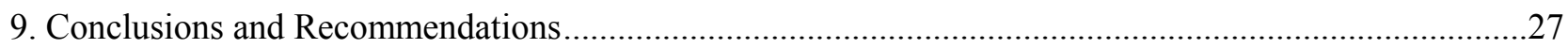

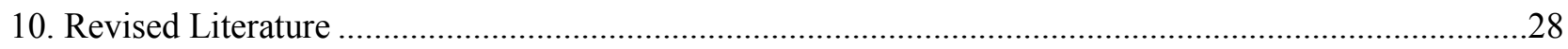




\section{LIST OF ACRONYMS}

AG

AIDESEP

ANP

BCRP

CONAM

CONAP

CTARU

DED

DESA

DGAA/E

DGAA/M

DGRA

DIGESA

DREM

D.S.

ECA

IBC

IDH

EIA

EM

FAO

FENACOCA

FONER

FSC

GEI

GN

GOREU

IIAP

IIRSA

INDEPA

INEI

INIEA

INRENA

LGN

LMP

MBDP

MDL

MIMDES

MINAG

MINEM

MW

OAJ

OIRA

OIT

OPA

OPD

ORAU

OSINERGMIN

PBI

PCM

PROCLIM

PRODUCE

RD

RM

RS

SAC

SERVINDI

SUNAT

TJ

TLC

TPC

US
Ministerio de Agricultura

Asociación Interétnica de Desarrollo de la Selva Peruana

Áreas Naturales Protegidas

Banco Central de Reserva del Perú

Consejo Nacional del Ambiente

Confederación de Nacionalidades Amazónicas del Perú

Consejo Transitorio de Administración Regional Ucayali

Servicio Alemán de Cooperación Social-Técnica

Dirección Ejecutiva de salud Ambiental

Dirección de Asuntos Ambientales Energéticos

Dirección de Asuntos Ambientales Mineros

Dirección General de Reforma Agraria

Dirección General de Salud Ambiental

Dirección Regional de Energía y Minas

Decreto Supremo

Estándares de Calidad Ambiental

Instituto del Bien Común

Índice de Desarrollo Humano

Estudio de Impacto Ambiental

Energía y Minas

Organización de las Naciones Unidas para la Agricultura y la

Alimentación

Federación Nativa de Comunidades Cacataibo de Padre Abad

Fondo Nacional de Electrificación Rural

Forest Stewardship Council

Gases de efecto invernadero

Gas natural

Gobierno Regional de Ucayali

Instituto de Investigaciones de la Amazonía Peruana

Iniciativas de Integración Regional de Sudamérica

Instituto Nacional de Desarrollo de los Pueblos Andinos, Amazónicos y Afroperuanos

Instituto Nacional de Estadística e Informática

Instituto Nacional de Investigación y Extensión Agraria

Instituto Nacional de Recursos Naturales

Líquidos de gas natural

Límites Máximos Permisibles

Millones de Barriles de Petróleo

Mecanismos de Desarrollo Limpio

Ministerio de la Mujer y Desarrollo Social

Ministerio de Agricultura

Ministerio de Energía y Minas

Mega Watz

Oficina de Asesoría Jurídica

Organización Indígena Regional de Atalaya

Organización Internacional del Trabajo

Oficina de Procedimientos Administrativos

Organismo público descentralizado (

Organización Regional Indígena AIDESEP Ucayali

Organismo Supervisor de la Inversión en Energía y Minas

Producto Bruto Interno

Presidencia del Consejo de Ministros

Programa de Fortalecimiento de Capacidades Nacionales para Manejar el Impacto del Cambio

Climático y la Contaminación del Aire

Ministerio de la Producción

Resolución Directoral

Resolución Ministerial

Resolución Suprema

Sociedad Anónima Cerrada

Servicio de Información Indígena

Servicio Nacional de Administración Tributaria

Terajoule

Tratado de Libre Comercio

Trillones de Pies Cúbicos

Estados Unidos de América 


\section{Energy Policy, Forests, and Local Communities in the Ucayali Region, Peruvian Amazon}

\section{Introduction}

The appropriate approach to energy policy is key for Amazon's development. The risks of negative impacts of energy policies are relevant for both the ecological processes and the related social dynamics. The fact that global warming and climate change influence biodiversity loss and therefore development alternatives for local communities suggests that the promotion of public policies for sustainable development cannot underestimate the energy aspect. This study analyzes processes and policies of energy development in the Ucayali Region of Peru, and particularly their impacts on local communities. The key research question that needs to be answered is: How energy policies impact local communities?

The objectives of the study are: i) assess existing energy policies at national and regional level that are relevant to forests and local communities in the Ucayali Region, ii) identify factors influencing the current status of energy policies and their impact on forests and the livelihoods of local communities, iii) recognize the environmental impacts related to energy policies, and iv) propose recommendations on energy policies to decision makers.

The context of the study features a national process of decentralization in which the administrative domain takes priority over the political domain, constraining local autonomy. Consequently, the official discourse of sustainable development in energy projects does not necessarily take into consideration indigenous peoples' environmental concerns and human rights. The distinction between rights on soil and subsoil is often a cause of conflict.

Interviews for this article were conducted with key actors from indigenous communities, regional government, and regional authorities. Likewise, information from indigenous workshops addressing communities' relation to hydrocarbons was systematized. In addition, the study included a comprehensive bibliographic review on the institutional structure regarding the country's energy sector, energy policies, and energy statistics.

\section{Study Area}

\subsection{Biophysical Aspects}

The Ucayali Region ${ }^{1}$ is located in the central Peruvian Amazon. Commonly known as lowland forest (selva baja), it includes lowland and upland forest ecosystems that are among the richest of the planet in biological production and diversity of flora and fauna, including several species that are typical of this habitat. Although lowland forests have to adjust to flooding conditions that slow down their growth, the outcome is generally positive and fast-growing species are also frequent (Tournon 2002). Ucayali is presently one of the most important regions in the country for timber extraction. The location of the Ucayali Region in Peru is shown in Figure 1.

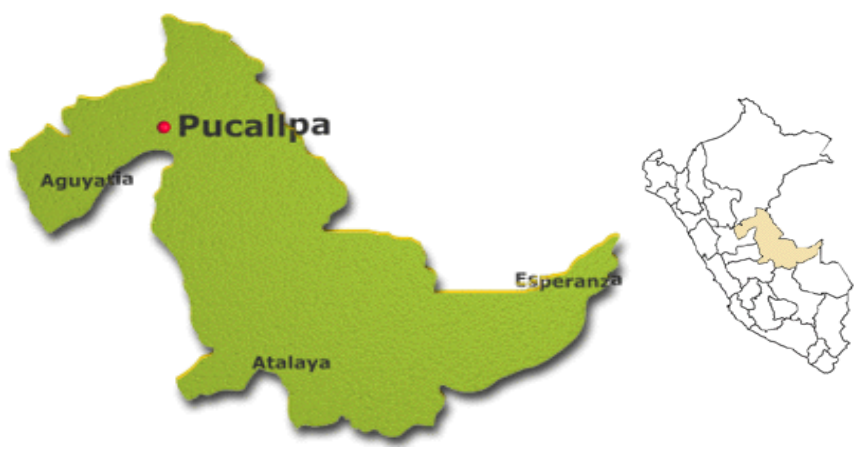

Figure 1: Location of the Ucayali Region

\footnotetext{
${ }^{1}$ Regions are political administrative units created in 2003 in Peru.
} 


\subsection{Economic Aspects}

Ucayali is an economically diverse Region where the service sector is predominant., followed manufacturing (including forestry), construction and agriculture. Mining and fishing stand out but with a smaller contribution. Table 1 lists the relative contribution of these sectors to the regional economy.

Table 1: Gross Domestic Product, 2006 (Million Nuevos Soles at current prices)

\begin{tabular}{|l|r|r|r|r|}
\hline Ucayali & $\mathbf{2 0 0 4}$ & $\mathbf{2 0 0 5}$ & $\mathbf{2 0 0 6}$ \\
\hline Services & 1,500 & 1,656 & 1,804 \\
\hline Manufacturing (including forestry) & 477 & 527 & 629 \\
\hline Construction & 182 & 233 & 290 \\
\hline Agriculture & 177 & 182 & 241 \\
\hline Mining & 56 & 66 & 83 \\
\hline Fishing & 18 & 20 & 25 \\
\hline Total GDP & $\mathbf{2 . 4 1 0}$ & $\mathbf{2 . 6 8 4}$ & $\mathbf{3 . 0 7 2}$ \\
\hline
\end{tabular}

Source: Perú en Números 2007 - Instituto Cuánto

The main economic corridors in the Ucayali Region are:

- West: Pucallpa - Aguaytia - Tingo Maria

- North: Pucallpa - Contamana

- South: Pucallpa - Masisea - Iparia - Atalaya

\subsection{Social Aspects}

$85.7 \%$ of the population in Ucayali has at least one unsatisfied basic need ${ }^{2}$ (Ministry of Economy and Finance, 2007). The situation in the Region can be better understood using the Human Development Index 2006 as shown in Table 2, comparing the country's 25 regions.

Table 2: Human Development Index (HDI) in Ucayali, 2006

\begin{tabular}{|c|c|c|c|c|c|c|c|c|c|c|c|c|c|}
\hline \multicolumn{2}{|c|}{ Population } & \multicolumn{3}{|c|}{ HDI } & \multicolumn{2}{c|}{$\begin{array}{c}\text { Life } \\
\text { Expectancy at } \\
\text { Birth }\end{array}$} & \multicolumn{2}{c|}{ Literacy } & \multicolumn{2}{c|}{$\begin{array}{c}\text { School } \\
\text { Attendance }\end{array}$} & \multicolumn{2}{c|}{$\begin{array}{c}\text { Educational } \\
\text { Achievement }\end{array}$} & $\begin{array}{c}\text { Per Capita Family } \\
\text { Income }\end{array}$ \\
\hline Inhabitants & Ranking & HDI & Ranking & Years & Ranking & $\%$ & Ranking & $\%$ & Ranking & $\%$ & Ranking & Soles/month & Ranking \\
\hline 402,445 & 18 & 0.57 & 12 & 68.2 & 17 & 94.7 & 7 & 84.2 & 17 & 91.2 & 8 & 232.9 & 15 \\
\hline
\end{tabular}

Source: PNUD, 2006

The Ucayali Region is home to about 300 indigenous communities, 220 of which are officially recognized, with an approximate population of 50,000 inhabitants who have been granted rights for the ownership of 1.9 million hectares of forests in their territories. Indigenous communities represent $40 \%$ of the area under forest extraction in the region, following the 2.9 million hectares of forest concessions $(60 \%)$. Forest concessions are used for timber and non-timber purposes through forest management plans. Concessions have a limited duration, renewable and require payment of development rights. Distinct capabilities across concessionaries and indigenous communities (due to organizational, economic, market and technological factors) refrain communities from obtaining greater benefits and turning their forest resources into wealth and a lever for their own development. However, ongoing promising forest management experiences by indigenous communities may provide some guiding principle to revert this process.

Population growth in Ucayali has resulted from migrations mainly of Andean people searching better life opportunities through the use of natural resources (soils, forests) and engagement in informal business. Even though Pucallpa is settled for more than a half century, the city shows severe deficiencies in urban organization and provision of basic services. The highway connecting Pucallpa with Tingo Maria is

\footnotetext{
${ }^{2}$ Unsatisfied Basic Needs (UBN) is a direct method to identify critical constraints in a certain population and to characterize poverty. It often uses indicators directly connected to four areas of people's basic needs (dwelling, water and sewage systems, basic education and minimum wage), available from demographic and housing surveys.
} 
seriously deteriorated. New paving is under way after decades, in the context of the Initiative for South America's Regional Integration (IIRSA), but a considerable extension still needs to be completed. The road and energy connection between Pucallpa and Cruzeiro do Sul, Brazil, is also expected. On March 24, 2008 the Peruvian Congress approved the construction of a railroad track between Brazil and Peru with an investment of 10.5 billion dollars (Zambrano 2008a). It is expected that the railroad will use natural gas to become an efficient, environmentally clean mode of transportation (Bernales 2008). Figure 2 shows the existing and proposed IIRSA works planned for Ucayali.

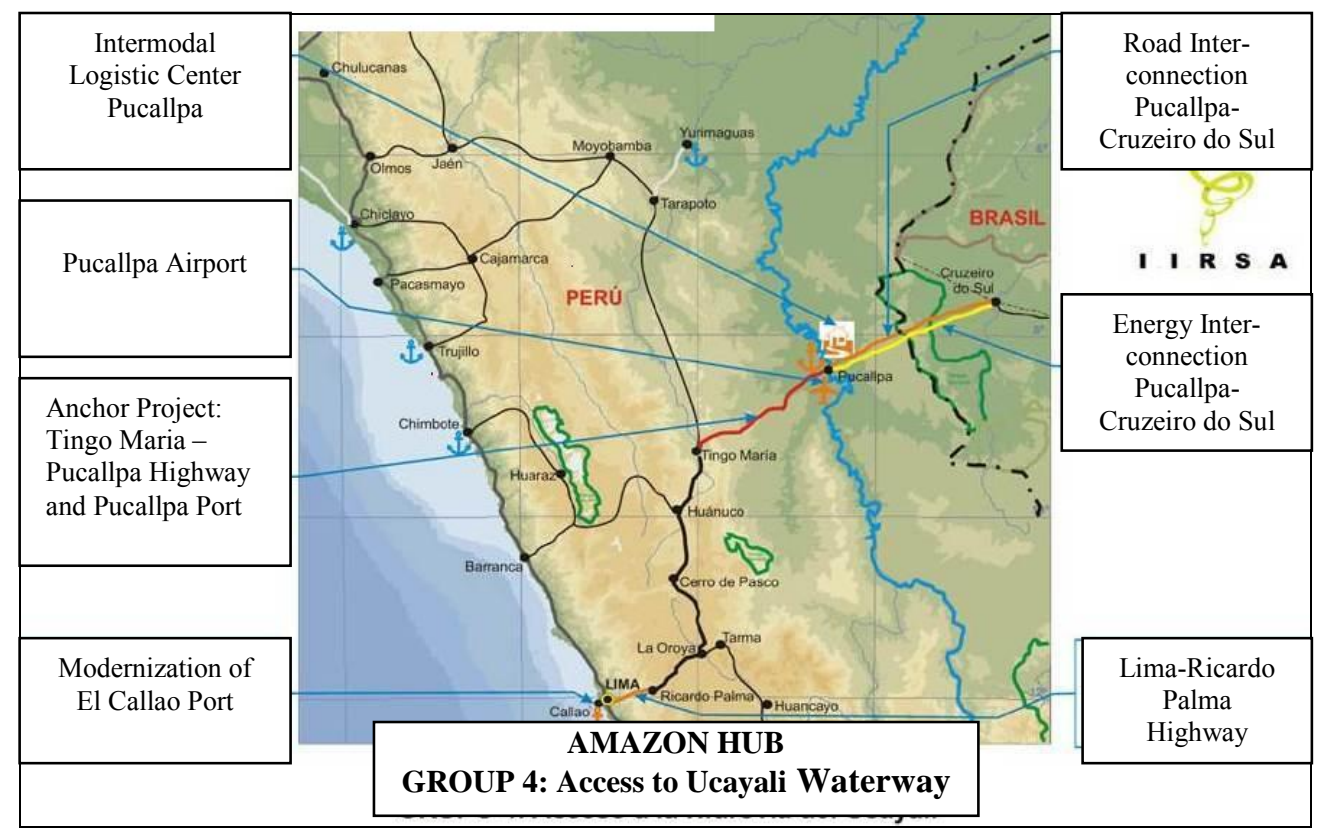

Figure. 2. Initiatives for the Regional Integration in South America (IIRSA) in Ucayali

\subsection{Cultural Aspects}

The Peruvian Amazon is home to approximately 300,000 indigenous people from 59 ethnic groups and who speak 15 languages. Some $95 \%$ of these people are integrated into the market with several variations in form and content. Over the last 40 years, these indigenous peoples have organized themselves to achieve legal status for their territories. Today, some 50 ethnic or inter-ethnic federations are affiliated to regional and national indigenous organizations. $5 \%$ of the indigenous population is isolated ${ }^{3}$ (Instituto del Bien Común, 2006).

The main language families in the Ucayali Region are shown in Table 3.

Table 3: Language Families and Ethnic Groups in the Ucayali Region

\begin{tabular}{|l|l|}
\hline $\begin{array}{c}\text { Language } \\
\text { family }\end{array}$ & \multicolumn{1}{c|}{ Ethnic Groups } \\
\hline Pano & $\begin{array}{l}\text { Amahuaca, Capanahua, Cashibo Cacataibos, Cashinahua, Chaninahua, } \\
\text { Cujareño, Iskobakeda (Isconahua). Mastanahua, Matsé Mayoruna, Murunahua, } \\
\text { Parquenahua, Pisabo, Sharanahua, Shetebo, Shipibo - Conibo, } \\
\text { Yaminahua. }\end{array}$ \\
\hline Arawac & $\begin{array}{l}\text { Amueshas, Campas Asháninkas, Nomatsiguengas, Campas from the Gran Pajonal, } \\
\text { Campas from the Upper Perené, Campas from Pichis, Campas from Ucayali, Culinas, } \\
\text { Chamicuro, Machiguengas, Piros, Yines, Ticunas. }\end{array}$ \\
\hline
\end{tabular}

Source: Ministry of Energy and Mines / GOREU, 2007

${ }^{3}$ Indigenous Peoples Living in Voluntary Isolation are those tribes in the Peruvian Amazon who have decided to keep themselves isolated from the rest of society to ensure their physical and socio-cultural integrity (AIDESEP 2008). 
The Shipibo-Conibo, the main ethnic group in the Region, is essentially a group of farmers and huntergatherers, including fishing. As property titles to forests cannot be granted by the State, communities own farmland but not forest or protected land, which are only licensed for use. Attempts from the current government to promote the integration of community lands into the market, and therefore allow their sale, were strongly refused by communities.

\section{Assessment of the Energy Sector}

\subsection{Energy in Peru}

Hydrocarbon reserves are found on almost 53 million hectares of the Peruvian Amazon's 78 million hectares (Gamboa 2007). A large portion of the Ucayali Region is subject to claims for oil prospection, a significant part being comprised by native communities' lands, including the so-called Territorial Reservations of Indigenous Peoples in Voluntary Isolation. Figure 3 shows the distribution of oil exploration and development blocks in the country.

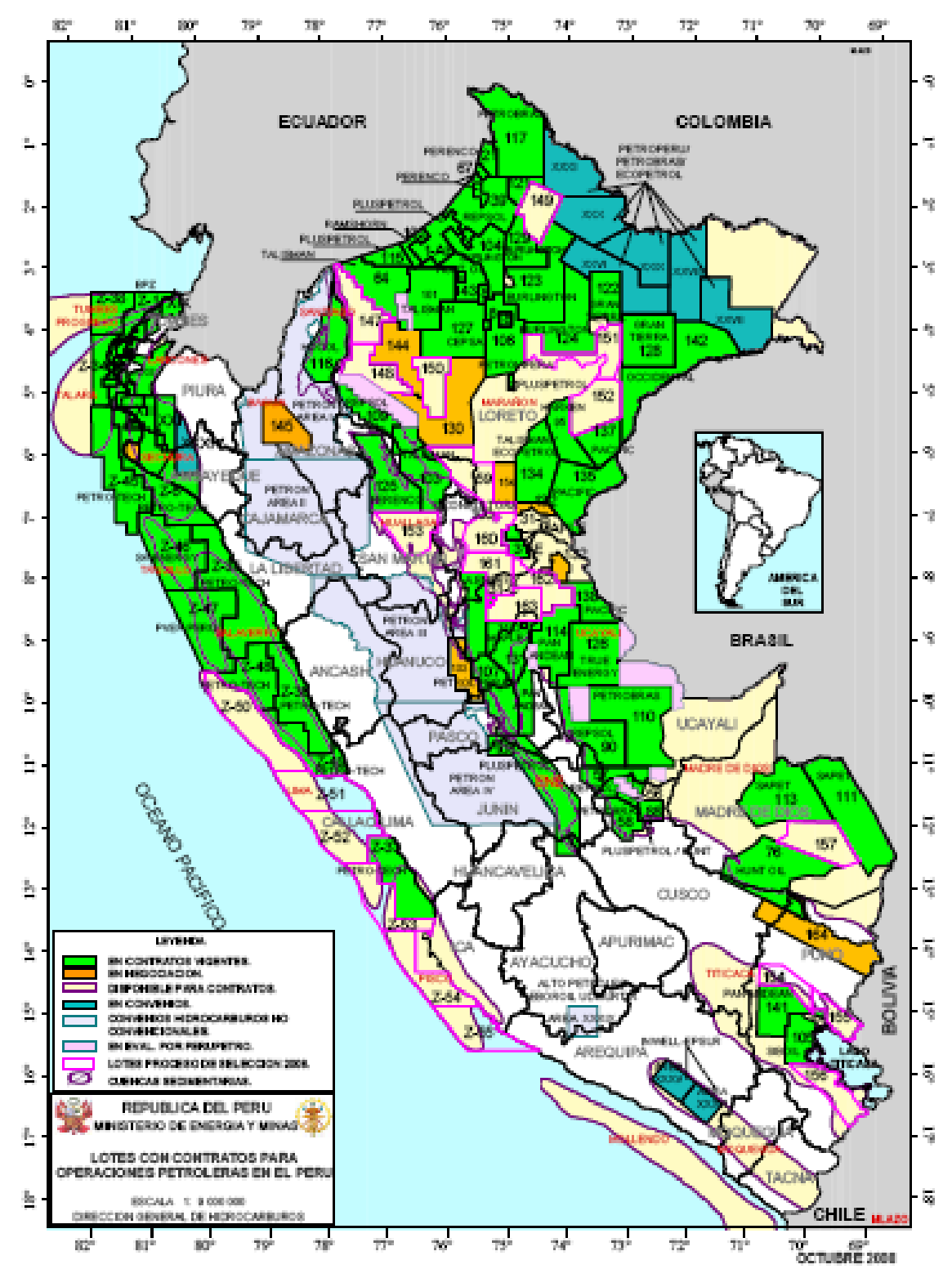

Figure 3: Oil exploration and development in the country. Source: MME 2008 
Hydrocarbon production in 2006 continued to show a substantial dynamism driven by extraction of natural gas that grew by $17 \%$ as compared to the previous year. Such performance was basically due to the Camisea Project ${ }^{4}$, as a result of greater demands by steam power stations and industrial enterprises. Likewise, production of liquid hydrocarbons increased by $3.9 \%$ in 2006, also influenced by Camisea (Banco Central de Reserva del Perú 2006).

The Ministry of Energy and Mines (2007a) reports that the demand for liquid hydrocarbon by-products during the 2007-2016 period will be strongly affected by the consumption of natural gas. A considerable increase in the demand for liquid fuels is thus expected in the next decade. The overall demand for hydrocarbons is increasing due to sustained growth in the country's business activity. It is estimated that in 2016 the overall demand for fuels derived from oil will be in the order of 158.9 million barrels of oil per day (MBPD), which means an annual average increase of $1.7 \%$. Furthermore, the overall demand for hydrocarbons (including natural gas) will increase at an annual rate of $6.3 \%$.

\subsection{Domestic Energy Production by Economic Sectors}

Domestic Energy Production (DEP) by economic sectors in Peru is shown in Table 4. Domestic production of mining and hydrocarbons' sectors represents somewhat less than $5 \%$ of the DEP, based on the sector's contribution to the GDP. This is approximately one third of the contribution of the manufacturing and of trading sectors. However, hydrocarbons directly affect both industrial development and household economy, as increased fuel prices increase production costs and are transferred to the price of the household shopping basket. Table 4 shows domestic gross production by sectors as of September 2007.

Table 4: Domestic Production by sectors as of September 2007 (Base Year 1994)

\begin{tabular}{|l|c|}
\hline \multicolumn{1}{|c|}{ Economic Sectors } & $\begin{array}{c}\text { Weight (corresponding to GDP structure rated } \\
\text { at basic prices) }\end{array}$ \\
\hline DOMESTIC PRODUCTION & $\mathbf{1 0 0 . 0}$ \\
\hline Farming & 7.60 \\
Fishing & 0.72 \\
Minerals and Hydrocarbons & $\mathbf{4 . 6 7}$ \\
Manufacturing & 15.98 \\
Electricity and Water & 1.90 \\
Construction & 5.58 \\
Trade & 14.57 \\
Other Services (Governmental Services, & 48.99 \\
Transports, Communications and other Services) & \\
\hline \multicolumn{2}{|c|}{ Sources: INEI, Ministry of Agriculture, Ministry of Energy and Mines, Ministry of Production and SUNAT } \\
\hline
\end{tabular}

Over the past few years income from natural resources has regained importance due to exceptional oil prices at international markets that reached US $\$ 140$ per barrel. However, significant drops in these prices occurred in 2008's second semester and by the end of the year such prices were below US\$50.

In Peru the great potential of rivers and lakes is used to generate electricity. This hydroelectric power accounts for $60 \%$ of the country's total electricity. The remaining $40 \%$ is generated by steam power stations using oil as its main fuel source (Museo de la Electricidad 2008).

\subsection{Energy Reserves}

The proven reserves of commercial energy (as of 2006) indicate the high potential of gas in Peru, justifying a governmental policy on domestic gas consumption. Gas is followed, in order of importance, by hydroelectric power, natural gas liquids, and crude oil. The data is presented in Table 5.

\footnotetext{
${ }^{4}$ The Camisea Project is a gas megaproject located in the Peruvian Amazon in the Camisea basin. It comprises the initial production of gas and liquid fuel reserves, while segmentation occurs in the country's coastal zone.
} 
Table 5: Proven Reserves of Commercial Energy, 2006 (TJ = terajoule)

\begin{tabular}{|l|r|r|}
\hline & Proven reserves (TJ) & Structure\% \\
\hline Natural Gas & 11593968 & 44.9 \\
Hydroelectric power & 5965666 & 23.1 \\
NG Liquids & 3607113 & 14.0 \\
Crude Oil & 2407573 & 9.3 \\
Coal & 1347225 & 5.2 \\
Uranium & 878639 & 3.4 \\
\hline Total & & $\mathbf{1 0 0}$ \\
\hline
\end{tabular}

Source: DGH, DGM, DGE

The San Martin and Cashiriari deposits, jointly known as Camisea's Block 88, host one of the most important natural gas reserves in Latin America. The deposits' proven on-site volume of gas is 8.7 trillion cubic feet (TCF) with an estimated final recovery of 6.8 TCF of natural gas (recovery factor: 78\%) and production of 411 million barrels of associated natural gas liquids (propane, butane and condensates). The potential of Block 88 is estimated to be 11 TCF of natural gas (when adding proven and probable on-site gas volume). The estimated final recovery may reach 8.24 TCF of gas and 482 million barrels of natural gas liquids. Camisea reserves are ten times bigger than any other reserve in Peru (CAMISEA 2008)

In January 2008, the Ucayali Regional Director of Energy and Mines reported the discovery in Block 57 (Sepahua) of 2 trillion cubic feet or 56 thousand million cubic meters of gas reserves, a quantity higher than the gas reserves in Aguaytia (reserves of 440 million cubic feet). Yet, reserves in Block 57 are five times smaller than Camisea's reserves in (Vilchez 2008d).

\subsection{Primary Energy Production}

Commercial energy in Peru is basically derived from crude oil, water energy and natural gas (including Natural Gas Liquids). The use of firewood across the country clearly stands out from non-commercial energy as shown in Table 6. In rural communities of the Amazon the use of firewood is widespread. The country is aware of the need to promote the use of cleaner, renewable energies, and their participation is expected to reach $33 \%$ in the domestic energy matrix in the next years ${ }^{5}$ (Gamio 2007).

Table 6: Primary Energy Production (TJ)

\begin{tabular}{|c|r|r|r|}
\hline \multirow{2}{*}{ Source } & \multicolumn{2}{|c|}{ Proven reserves (TJ) } & $\begin{array}{r}\text { Variation } \\
(\%)\end{array}$ \\
\cline { 2 - 4 } Commercial Energy & 2005 & 2006 & \\
$-\quad$ Crude Oil & 159479 & 163958 & 2.8 \\
$-\quad$ Water Energy & 80567 & 88131 & 9.0 \\
$-\quad$ Natural Gas + NGL (*) & 130663 & 145489 & 11.3 \\
$-\quad$ Coal & 1249 & 3136 & 151.2 \\
Sub-total & 372248 & 400715 & 7.6 \\
Non-commercial Energy & & & \\
$-\quad$ Firewood & & & \\
$-\quad$ Bagasse & 77227 & 80132 & 17.8 \\
$-\quad$ Dung and Yareta & 11929 & 13958 & -1.2 \\
$-\quad$ Solar Energy (**) & 10368 & 10243 & 0.6 \\
Sub-total & 2323 & 2337 & 4.7 \\
\hline Total & 101848 & 106671 & 100 \\
\hline
\end{tabular}

(*) Regulated production

(**) Estimated

Source: Ministry of Energy and Mines 2007b.

\footnotetext{
${ }^{5}$ The figure of $33 \%$ derives from the fact that a somehow proportional contribution from several sources of energy is obtained by decreasing the origin of energy from non-renewable sources and increasing the participation of energies from renewable sources.
} 


\subsection{Energy in Ucayali}

Within Peruvian's electric infrastructure, since 2002 the zone of Pucallpa is part of the National Interconnected Electric Power System, and the Aguaytia Isolated Electric Power System, while the zone of Atalaya has its own Isolated Electric Power System. Energy generation for Ucayali is shown in Table 7.

Table 7: Electric Energy Generation in Ucayali

\begin{tabular}{|l|l|c|c|c|c|}
\hline $\begin{array}{c}\text { Electricity } \\
\text { Service }\end{array}$ & $\begin{array}{c}\text { Steam/ Water } \\
\text { Energy } \\
\text { Generating } \\
\text { Sets }\end{array}$ & Quantity & $\begin{array}{c}\text { Rated Power } \\
\text { (MW) }\end{array}$ & $\begin{array}{c}\text { Rated Power } \\
\text { (MW) }\end{array}$ & $\begin{array}{c}\text { Active } \\
\text { Power } \\
(\text { MW) }\end{array}$ \\
\hline \multirow{2}{*}{ Pucallpa } & Wartsila & 4 & $\mathbf{6 . 3 4}$ & $\mathbf{2 5 . 3 6}$ & $\mathbf{2 4 . 0 0}$ \\
\cline { 2 - 6 } & Caterpillar & 1 & $\mathbf{0 . 5 0}$ & $\mathbf{0 . 5 0}$ & $\mathbf{0 . 4 5}$ \\
\hline \multirow{3}{*}{ Atalaya } & Caterpillar & 1 & $\mathbf{0 . 5 0}$ & $\mathbf{0 . 5 0}$ & $\mathbf{0 . 3 8}$ \\
\cline { 2 - 6 } & Suizer & 1 & $\mathbf{0 . 1 5}$ & $\mathbf{0 . 1 5}$ & $\mathbf{0 . 1 3}$ \\
\cline { 2 - 6 } & Kubota & 1 & $\mathbf{0 . 2 4}$ & $\mathbf{0 . 2 4}$ & $\mathbf{0 . 2 0}$ \\
\hline & & & Sub-total & $\mathbf{0 . 8 9}$ & $\mathbf{0 . 7 1}$ \\
\hline & & & Total & 26.75 & 25.16 \\
\hline
\end{tabular}

Source: Electro Ucayali 2008

According to Ucayali's government, the regional coverage of the public electric lighting service is $60.7 \%$. Another $31.7 \%$ of the households use oil lamps, while $7.6 \%$ have no lighting service.

Some gas companies also operate in Ucayali (Aguaytia and Camisea). Current average production of natural gas is 66.75 million cubic feet per day (Ministry of Energy and Mines/GOREU 2007). There is also oil prospection and production in the region, although the latter only reaches 387 thousand barrels of crude oil in Blocks 31-B and 31-D as stated in GOREU's Agreed-Upon Regional Development Plan 2004-2006. Regional availability of oil (4.2 billion barrels) and gas (284 billion cubic feet) respectively represent $67 \%$ and $99 \%$ of the potential of total existing resources as mentioned in the Agreed-Upon Regional Development Plan for Ucayali as of 2010.

\section{Political, Institutional and Policy Framework}

Public policies, understood as guidelines and directives enabling the promotion and safeguard of citizens' rights, must result from a consensus between rulers and civil society. In incipient democracies the general perception often relates policy-making as an exclusive responsibility of the administration of the moment. The problem, based on such understanding, rather than being the extent to which civil society's participation is promoted, is the extent to which people are aware of government decisions. From this perspective, governance issues are reduced to communication strategies.

A consistent policy framework is not enough for enhanced governance. It needs to be combined with a proper institutional structure, an appropriate organizational culture and mechanisms for policy enforcement. The ongoing decentralization process in Peru should therefore contribute to the reform of the State which in turn may further the country's democratization, effective government management, and the active exercise of citizens' rights. This approach also requires democratization in the management of renewable and nonrenewable natural resources, where the interests of the State may be combined with those of local governments. This section thus discusses the needed political, institutional and policy framework that links energy development, forests and local communities.

\subsection{Political Framework}

\subsubsection{National level}

The Ministry of Energy and Mines (MME) should safeguard the interests of the State while promoting private investments in electricity, hydrocarbons and mining. This includes direct involvement of the State in 
the expansion of the rural power system, with interventions based on social criteria. Furthermore, the MME guides proper relationships between producers and consumers through its regulations. It furthers private investment, free competition, and efficient, productive energy-mining development. It operates seeking a balance between social and environmental issues and promotes poverty alleviation across the country (MME 2008). The level of environmental and social concern is however conditional to the investment needs. This is the explanation for State attempts to reduce the importance of community and indigenous territories, or to reduce protected areas regardless of the consent of INRENA. The State acknowledges the right to use forest soil for subsistence or commercial purposes through forest permits. It however keeps for itself property rights in the subsoil and resources thereof. Concession rights for both renewable and nonrenewable natural resources in lands of native communities or Territorial Reservations are not granted. Tensions thus arise under many forms between national development requirements and the perspectives of regions and towns.

Furthermore, the Energy and Mining sector has the 2011 goal of ensuring energy supply at competitive costs to the extent required by a growing economy within an institutional framework that promotes the country's sustainable development. The following objectives have been set for that purpose: i) To change the current Peruvian energy matrix through the development of primary sources available in the country (natural gas and water) and stop consuming what the country does not produce and import (especially diesel oil); ii) To promote the sustainable development of renewable energy sources: water, geothermal, wind, solar energy, and biofuels as well. This is consistent with the National Agreement which in its nineteenth government policy (Sustainable Development and Environmental Management) states that "it will promote the environmental investment and technology transfer for the generation of cleaner and competitive industrial, mining, transport, sanitation and energy activities..."

In order to promote renewable energies in Peru by way of private/decentralized initiatives, Diaz (2006) proposes the following: i) accessibility to energy potential studies (solar, aeolian, water, and other maps); ii) Establishment of a widely accepted methodology to identify social benefits derived from rural energy: productive uses, education, health care, deforestation control, frontier occupation, and iii) definition of competitive funds to co-finance pilot projects using renewable energies, as does the Fund for Rural Electrification (FONER, in Spanish).

Operations of the Ministry of Energy and Mines are based on the belief that productive capacity, raising of foreign funds and social management can be harmonized within the sustainable development framework (Gamio, 2007). Yet, this discourse is difficult to materialize due to the high level of conflicts between communities and extractive companies, which were widely documented by the Ombudsman's Office in its special report: socio-environmental conflicts because of extractive activities in Peru (Ombudsman's Office 2007).

\subsubsection{Regional Level}

Regional policy on energy development is an extension of the national policy. It is worth mentioning that although Peru is promoting a decentralization process through which specific functions are assigned to Regional Governments, poor implementation due to lack of material and financial resources does not allow greater autonomy in these developments. Energy concession contracts are directly signed between PERUPETRO and energy companies, and when granted on lands that overlap with native communities, the latter are notified directly.

In January 2008 the Regional Government of Ucayali (GOREU, in Spanish) and PERUPETRO signed a Statement on Strategic Alliance which purpose are joint efforts for investments in hydrocarbon exploration and development. Both institutions argue that such activities will respect social and environmental aspects, and promised to protect native communities located in the hydrocarbon exploration blocks (AHORA 2008). Although the Environmental Action Plan for Ucayali sets out the preparation of a biannual impact report on the oil activity, there is no knowledge of such report.

A major issue expressed by regional authorities and leaders is the increased benefits resulting from the oil and gas development, both inside the region and in surrounding areas. The Ucayali River is used to 
transport machinery and exploration equipment and receive waste contaminants from the gas plant in Camisea. The Ucayali Regional Mining Bureau thus suggests that the Camisea gas pipeline should reach as far as the Port of Pucallpa and that the Ucayali basin should be included in the impact zone of the Camisea Project, allowing fundraising to prevent environmental contingencies (Vilchez 2008c). In addition, as of April 2008 the petitions sent for using 50\% of the Aguaytia gas revenues (called in spanish "canon") did not arise any interest from the Executive (Zambrano 2008c).

Even though the Regional Government of Ucayali is aware of the growing prospects for biofuels in the Amazon, it raises many concerns on the advisability of promoting crops for such purpose due to the fear of massive deforestation that it may cause. The private sector has been considering using deforested areas for biofuel crops. The company Etanol Ucayali is considering planting one million hectares of sugar cane using existing degraded lands. They argue that 25,000 direct and 100,000 indirect jobs will be created, and that no forest land will be used (Macedo 2007a). In November 2007, the National Agriculture Research Institute, INIA, provided 4,000 sugar cane seedlings for the company, which are intended for propagation (Macedo $2007 \mathrm{c}$ ). A project launched by the national government will reforest 75,000 hectares of deforested areas in the regions of San Martin, Ucayali, Loreto and Huanuco, and the initial 3,700 hectares were planted with oil palm in Ucayali in January 2008. Another 5,000 hectares of oil palm are targeting biodiesel production (Vilchez 2008a). It should be noted that the Forest and Wildlive Law 27308 included oil palm as a species for reforestation, a mistake repeated in Legislative Decree 1090, which is now strongly contested because of its vested interests to promote biofuels.

The president of the Research Institute of the Peruvian Amazon (IIAP) considers that ten million hectares already deforested in the Amazon can be used for sugar cane, castor-oil plant, jatropha, and oil palm with the purpose of extracting biofuels and reducing emissions of contaminants (Quispe 2007b). The promotion of biofuels has been nevertheless the object of some criticism since greenhouse gases (GHG) are released in the production process, eventually at even greater levels than the use of fossil fuels would have caused (Veen 2007). In this regard, Coello (2007) warns about the competition between energy crops and crops for human consumption, especially for land and water. Similarly, FAO's sub-director general warned that the growing production of biofuels may endanger the MDG goals to end hunger in developing countries.

The agreed-upon Development Plan for the Ucayali Region 2004-2006 sets the following goals: i) formal and diversified mining activity, ii) extended energy frontier taking into account non-traditional alternative sources $^{6}$, iii) self-supply of hydrocarbons, iv) regional market for natural gas fully developed, v) extreme safety of workers involved in and the society affected by exploratory, productive and processing activities, both for mining and energy development, and vi) promotion of a conservation culture and noncontamination of the environment.

In July 2007 the region witnessed a strike for undetermined time to protest against the national government and preventing the elimination of a special tax-exemption regime in the Amazon that was implemented to promote investments and to generate greater income from gas revenues ${ }^{7}$ as set forth by the Peruvian law. The claims of the protesters included, among other issues: i) the "increase in oil excess revenues (sobrecanon) from $2.5 \%$ to $15 \%$ of the production value, and allocation of $50 \%$ of these revenues to the development of new deposits at regional level", and ii) "regional allocation of $50 \%$ from income taxes, royalties and a percentage of the values of contracts related to the production of gas in the Ucayali Region (Aguaytia and others) and other areas that exert an impact in the region (Camisea and Pagoreni)."

The National Government has argued that tax exemptions provided by the 1998 Law of Investment Promotion for the Amazon (Law 27037) to facilitate sustainable and comprehensive development of the area were not effective and should be eliminated. Indicators show that the goals set by Law 27037 have not been achieved. Cumulative growth from 1999 to 2005 was about 20\% for the Amazon, compared to 28\% for the other departments. Moreover, tax exemptions such as the General Sales Tax (IGV, in Spanish) for

\footnotetext{
${ }^{6}$ For instance, solar energy's great potential in Ucayali (with its solar radiation of $5-5.5 \mathrm{kwh} / \mathrm{m} 2 /$ day) should be endorsed by a more emphatic promotion policy.

7 Termed as "Canon" this mechanism provides the effective and adequate share for regional and local governments in the total revenues and taxes obtained by the State from the use of natural resources.
} 
the entire Amazon and the Excise Tax (ISC, in Spanish) on fuels in Loreto, Ucayali and Madre de Dios has not lowered prices for such an important and crucial sector as Food and Beverages (Ministry of Economy and Finance 2007). However, the outright public rejection (led by regional leaders) through the 2007 strike has preempted the federal government attempt, and exemptions are due to last until 2012.

\subsection{Institutional Framework}

Environmental management in Peru is complex and dispersed. It results difficult for the National Environmental Council (CONAM, in Spanish), the National Environmental Authority, to perform its duties effectively. It performs with little visibility, lack of political weight and insufficient financial resources. After 13 years of CONAM's existence Peru does not have an environmental policy (Ombudsman's Office 2007). Dispersion in more than 35 ministerial agencies and entities contributes to weakening the environmental management system. Luna (2007) says that "each sector watches and resolves from its own corner and for its own benefit the conflicts that may come along the way, even though more than one ministry is always involved. In those cases, everybody will be guilty, but it will be nobody's responsibility." Each sector has an internal environmental office which in several instances judge situations for which they are interested parties. The Ministry of Energy and Mines, for instance, includes General Bureaus of Electricity, Electrification, Hydrocarbons, Mining, Mining Environmental Issues, and Energy Environmental Issues.

To address this issue, in mid-2008 the Executive created the Ministry of the Environment through Legislative Decree $\mathrm{N}^{\mathrm{o}} 1013$, absorbing CONAM. The current configuration, however, is not necessarily meeting all the expectations towards a unified authority. The creation of the Ministry of the Environment honored international commitments established through the Free Trade Agreement (FTA) with the United States and responding to conditions imposed by the United States to extend a loan for the second part of the Camisea gas project (Lanegra 2008).

The institutional framework connected with the energy development is nationally and regionally broad. Table 8 lists the main institutions related to energy development in Peru.

Table 8: Main National and Regional Institutions related to Energy Development and Environment

\begin{tabular}{|c|c|c|c|}
\hline Scope & Name & Functions & Role \\
\hline National & $\begin{array}{l}\text { Ministry of } \\
\text { Energy and Mines }\end{array}$ & $\begin{array}{l}\text { Responsible for promoting the sustainable development } \\
\text { of energy and mining activities, furthering private } \\
\text { investment in a global, competitive framework and } \\
\text { facilitating harmonious relations in the sector. The } \\
\text { MINEM includes the Bureau of Mining Environmental } \\
\text { Issues and the Bureau of Energy Environmental Issues. }\end{array}$ & Regulatory \\
\hline National & $\begin{array}{l}\text { Ministry of the } \\
\text { Environment }\end{array}$ & $\begin{array}{l}\text { Regarding energy issues, the Ministry has the following } \\
\text { functions: } \\
\text { - Prepare the Environmental Quality Standards Plan } \\
\text { (EQS, in Spanish) and Maximum Permissible Limits } \\
\text { (MPL) which must include the stakes of the relevant } \\
\text { sector. } \\
\text { - Apply the guidelines, methodologies, processes and } \\
\text { plans for application of the EQSs and MPLs, which } \\
\text { must be implemented by public agencies in the scope } \\
\text { of their jurisdiction } \\
\text { - Promote innovative environmental technologies } \\
\text { - Design, approve and supervise the application of } \\
\text { preventive, control and environmental rehabilitation } \\
\text { instruments related to solid and hazardous wastes, } \\
\text { control and reuse of liquid effluents, air quality, toxic } \\
\text { and hazardous substances and sanitation, in order to } \\
\text { ensure an optimal environmental quality. }\end{array}$ & Technical-regulatory \\
\hline
\end{tabular}




\begin{tabular}{|c|c|c|c|}
\hline National & $\begin{array}{l}\text { PETROPERU } \\
\text { S.A }\end{array}$ & $\begin{array}{l}\text { Meets the energy needs of the domestic market with } \\
\text { competitive products and prices, generating and } \\
\text { promoting competition in the market. }\end{array}$ & Energy supplier \\
\hline National & $\begin{array}{l}\text { PERUPETRO } \\
\text { S.A. }\end{array}$ & $\begin{array}{l}\text { State-owned Company under private law, responsible for } \\
\text { encouraging the investment in hydrocarbon exploration } \\
\text { and development activities in the country }\end{array}$ & Investment promoter \\
\hline National & $\begin{array}{l}\text { OSINERGMIN } \\
\text { Energy and Mining } \\
\text { Investment } \\
\text { Supervising } \\
\text { Agency }\end{array}$ & $\begin{array}{l}\text { Responsible for supervising the correct supply of energy, } \\
\text { efficiently regulating the electricity and natural gas } \\
\text { utilities, and promoting policy development of the sector, } \\
\text { acting accordingly with autonomy and transparency }\end{array}$ & Supervisor \\
\hline National & $\begin{array}{l}\text { Project FONER } \\
\text { Fund for Rural } \\
\text { Electrification }\end{array}$ & $\begin{array}{l}\text { Responsible for promoting the development of rural } \\
\text { electrification, productive use of energy and utilization of } \\
\text { renewable energies, within an adequate legal and policy } \\
\text { framework }\end{array}$ & $\begin{array}{l}\text { Rural Electrification } \\
\text { Promoter }\end{array}$ \\
\hline National & $\begin{array}{l}\text { INRENA } \\
\text { Natural Resource } \\
\text { Institute }\end{array}$ & $\begin{array}{l}\text { Responsible for taking the required steps for the } \\
\text { sustainable use of renewable natural resources, } \\
\text { safeguarding the conservation and sustainable } \\
\text { management of the rural environment and wild } \\
\text { biodiversity. As national authority, it should perform its } \\
\text { work in close relationship with regional and local } \\
\text { governments, the organized civil society and public and } \\
\text { private institutions. }\end{array}$ & Regulatory \\
\hline Regional & $\begin{array}{l}\text { Bureau of Energy } \\
\text { and Mines of the } \\
\text { Regional } \\
\text { Government of } \\
\text { Ucayali }\end{array}$ & $\begin{array}{l}\text { Responsible for promoting the private investment in } \\
\text { energy and mining activities, within a competitive legal } \\
\text { framework towards a sustainable development, } \\
\text { encouraging the investigation and training, and } \\
\text { contributing at the same time to the preservation of the } \\
\text { environment, and achieving a safe conservationist } \\
\text { culture, and harmonious relations between the actors: } \\
\text { state-company-community. }\end{array}$ & $\begin{array}{l}\text { Private investment } \\
\text { promoter at regional } \\
\text { level }\end{array}$ \\
\hline Regional & $\begin{array}{l}\text { Electro Ucayali } \\
\text { S.A. }\end{array}$ & $\begin{array}{l}\text { Is the state-owned electricity company in the department } \\
\text { of Ucayali that carries out the power generation, } \\
\text { transmission and distribution activities within the } \\
\text { framework of the Electric Power Concession Law and its } \\
\text { enabling regulations }\end{array}$ & $\begin{array}{l}\text { Electric } \quad \text { services } \\
\text { provider }\end{array}$ \\
\hline
\end{tabular}

Source: Prepared using institutional information taken from websites.

The institution directly related to the defense of rights of native peoples' is the National Institute for Development of Andean, Amazonian and Afro-Peruvian Peoples (INDEPA, in Spanish); however, the Peruvian Government decided on February 23, 2007 to dissolve and turn INDEPA into a Bureau of Native Peoples, inside the Ministry of the Women and Social Development (MIMDES, in Spanish). The State thus reverted seven years in terms of native peoples' public institutionality. INDEPA was a decentralized public agency (OPD, in Spanish) with autonomy and hierarchy at ministerial level, reporting directly to the Presidency of the Cabinet Council, and was downgraded to a much lower hierarchical and functional level (IWGIA 2008). It has now very little scope of action in cases of native peoples' human rights violation regarding extractive activities.

The policy domain features legal inconsistencies, laws that are disobeyed or not laid down (such as Law 27446 governing Environmental Impact Assessment procedures), and serious limitations to enforce the law. Even when policies exist their implementation is prevented by the weakness and loss of credibility of 
environmental management instruments ${ }^{8}$. As far as December 2007 none of the 29 government-supported policies on Environmental Quality Standards (EQSs) nor the Maximum Permissible Limits (MPLs) were approved (Lanegra 2008). This was in part corrected on May 2008 when Supreme Decree $\mathrm{N}^{\circ}$ 037-2008implemented the Maximum Permissible Limits for effluent discharges for the hydrocarbon sector.

In addition to institutional dispersion, other constraints are the incipient development of environmental standards and the fact that the approval of environmental impact studies by the Ministry of Energy and Mines (MINEM) determines the scope of supervision. The Ombudsman's Office (2007) says that OSINERGMIN has no instruments to guarantee the protection of the vital space, since it does not set maximum permissible limits nor intervene in the evaluation of environmental impact assessments. The inspection, supervision and punishment system results ineffective as more than $50 \%$ of the imposed fines are reverted by judicial proceedings (Bernales 2007).

Management and planning mistakes are also product of a high level of political interference. In addition, specific situations are not properly dealt due to the lack of resources and special technical skills, as shown in Table 9:

Table 9: Institutional Problems for Scientific Proof of Impacts by the Hydrocarbon Activity

\begin{tabular}{|l|l|}
\hline \multicolumn{1}{|c|}{ Need for Scientific Proof } & \multicolumn{1}{c|}{ Institutional Problem } \\
\hline Levels of water, air and soil contamination & $\begin{array}{l}\text { The General Bureau of Environmental Health } \\
\text { (DIGESA, in Spanish) does not have technical and } \\
\text { financial means to perform its duties effectively. }\end{array}$ \\
\hline Effects of environmental contamination on people & $\begin{array}{l}\text { Doctors are not always able to diagnose heavy } \\
\text { metal intoxication and confound the symptoms } \\
\text { with other diseases. }\end{array}$ \\
\hline
\end{tabular}

Source: Ombudsman's Office 2007.

Environmental management instruments are also problematic. The EIA detected that guidelines are not binding or are not updated with international standards. Terms of reference are not enforceable and the final authorization is conditional upon the MINEM (General Bureau of Mining / Energy Environmental Issues DGAAM/E, in Spanish); not being trans-sectoral. Additionally, information-oriented workshops and public consultations prior to approval of the EIA are less effective (Bernales 2007).

Table 10 shows the problems with the environmental quality standards.

\begin{tabular}{|l|l|}
\hline \multicolumn{2}{|l|}{ Table 10: Problems with the Environmental Quality Standards } \\
\hline Air & $\begin{array}{l}\text { Air standards presents relevant gaps and its levels are far from those recommended } \\
\text { by the World Health Organization. }\end{array}$ \\
\hline Water & Water quality environmental standard was approved in 1969 \\
\hline Soil & There is no standard. \\
\hline
\end{tabular}

Source: Ombudsman's Office 2007

The existing Environmental Management System is not properly implemented. Population's perception is that hydrocarbon and mining are issues related to conflicts. The State demonizes environmental NGOs and underestimates local reactions. It does not allow much room for citizens' proposals. Social and environmental surveillance roles for NGOs are regarded as unpatriotic, and NGOs are viewed as an obstacle for smooth investment flow. Local, decentralized decision-making is feared to affect such investments (Ombudsman's Office 2007).

For the country's development it is important for the Peruvian State to face the actual environmental challenge. The World Bank's 2006 report states that the environmental degradation cost in the country is in

\footnotetext{
${ }^{8}$ This is the case for mechanisms such as the environmental impact assessment, adequacy and environmental management programs, quality standards, air standards and the initiative for the clean air law, and resistance to use financial mechanisms and incentives (Pulgar-Vidal 2007).
} 
the order of 3.9\% of the 2003 Domestic Gross Product, while the State only invests $0.3 \%$ of its GDP in environmental matters (Salazar 2008).

\subsection{Policy Framework}

The framework governing energy development is very wide. The problem, rather of being the lack of rules, is related to the lack of capabilities for implementation. Yet, alternatives are to continue improving the policy framework and what needs to be examined are the conditions for enforcement. The following cases can be found at national and regional levels:

- There are policies but there are no rules

- There are rules but there are no policies

- Rules are mixed with policies

- There are laws but they are not regulated

- There are regulatory laws but no budgets to implement them

- There are actions that are not necessarily in line with policies

In any sector, the existence of a Law is not enough to produce change. An appropriate institutional framework is required, and that relies on proper governance composed by organizational development, organizational behavior, and organizational culture. Not only the contents are needed, but also the knowledge and practices related to it. The legal framework regulating the interface among energy policies, forests and local communities is thus dependent on effective management ${ }^{9}$.

Supreme Decree 063-2005 of the Ministry of Energy and Mines promotes massive use of natural gas by the Peruvian population (Monsalve 2005). It targets the industrial, commercial, domestic and vehicular sectors throughout the national territory, by incorporating favorable conditions that facilitate consumers' access to natural gas. Sánchez (2007) states that such strategy is not only about replacing fuels, but also about promoting sustainable demands.

Supreme Decree No. 053-2007-EM declares of national interest the promotion of the efficient use of energy. It has been regulated by Law No. 27345. It helps ensuring proper supply of energy, enhancing the country's competitiveness, generating exportable energy surpluses, reducing environmental impacts, protecting consumers and strengthening people's awareness on the importance of efficient use of energy in several services of the economy by using equipment and technologies with better energy performance, good practices, and good shopping habits.

The regulation for the Law on the Promotion of Fuel Market (Supreme Decree No 013-2005-EM) mentions in Article 6 that the percentage of ethanol in gasoline sold in the country will be 7,8\%. Article 7 states that starting on January 1, 2008 ecological gasoline will be produced and sold in several regions, including Ucayali. Article 9 states that in the same date, ecological diesel oil (numbers 1 and 2) will be sold in several regions, including Ucayali.

Supreme Decree No 046-93-EM regulates Environmental Protection in Hydrocarbon Activities through nation-wide rules and provisions for the exploration, transformation, transport, sale, storage and related activities. It promotes the use of hydrocarbon resources in such a manner as to prevent adverse

\footnotetext{
${ }^{9}$ The most relevant laws for the study are as follows: Political Constitution of the Republic, General Environmental Law (Law 28611), Forest and Wild Fauna Law (Law 1090), Basic Law on Hydrocarbons (Supreme Decree $\mathrm{N}^{\circ} 042-$ 2005-EM), Updated Law on Hydrocarbons (Law 27377), Law on the Promotion of the Natural Gas Industry (Law 27133), Law on the Promotion of Investment in the Amazonia (Law 27037), Oil Revenues (Canon) Law and its amendments, General Mining Law, Electric Power Concession Law, Law on the Promotion of the Efficient Use of Energy, among others.
} 
environmental and/or social impact, following relevant legal provisions connected to sustainable development ${ }^{10}$ (Ministry of Energy and Mines 2008).

The Oil Revenues Law 27596 sets that regions that are sources of natural resources (eg.: Aguaytia) should be given $50 \%$ of royalties and income tax derived from their access. An amendment to the Law through a Supreme Decree issued during the Fujimori administration reduced the share to $10 \%$. Ucayali was therefore prevented from receiving annual incomes of 44 million nuevos soles (Zambrano 2008c).

The Oil and Excess Revenues are the actual share of local (provincial and district municipalities) and regional governments in the total revenues and taxes derived by the State from the development of such natural resource in said areas. The share of oil revenues for the development activities carried out in the departments of Loreto and Ucayali is $10 \%$ ad valorem of total oil production, and the share of oil excess revenues is $2.5 \%$ of the oil production value in those areas (Ombudsman's Office 2007). The institutional distribution percentages of these revenues in the department of Ucayali include $52 \%$ for the Regional Government, $2.5 \%$ for the National University of Ucayali, 2.5\% for the National Intercultural University of the Amazon, 3\% for the Research Institute for the Peruvian Amazon and 40\% for City Councils in the department.

\section{Environmental Impacts of Energy Projects in the Ucayali Region}

Impacts reported by native communities are mainly related to oil and gas spills, water contamination of rivers with lubricants, excessive surface traffic on rivers, and disturbing noises from helicopters and boat engines. These effects have not been successfully minimized by mitigation measures in place despite of the Environmental Impact Studies conducted (Ministry of Energy and Mines / GOREU 2007). Table 11 presents the impacts of hydrocarbon projects as reported by native communities, while Table 12 shows impacts as reported by the Ombudsman's Office.

Table 11: Impacts of hydrocarbon projects according to native communities

\begin{tabular}{|c|c|c|}
\hline Social Impact & Cultural Impact & Environmental Impact \\
\hline $\begin{array}{l}\text { - Corruption: leaders and community members } \\
\text { - Internal conflicts within indigenous } \\
\text { communities and grassroots organizations } \\
\text { - Loss of leadership and authority due to } \\
\text { personal interests } \\
\text { - Community abandonment } \\
\text { - Damages to agriculture } \\
\text { - Local products not paid by oil companies } \\
\text { - Spread of previously unreported sexually } \\
\text { transmitted infectious diseases. } \\
\text { - Women from native communities sexually } \\
\text { - Assaulted by company personnel } \\
\text { - Pelations with indigenous women } \\
\text { - Prostitution } \\
\text { - Alcoholism and consequent violence against } \\
\text { - Accidents } \\
\text { - Diseases and deaths allegedly by } \\
\text { consumption of contaminated water and fish } \\
\text { - Confusion due to lack of transparency }\end{array}$ & $\begin{array}{l}\text { - Discrimination of } \\
\text { indigenous peoples and } \\
\text { their culture } \\
\text { - Loss or weakening of } \\
\text { indigenous identity and } \\
\text { sudden changes in the } \\
\text { community's cultural } \\
\text { life } \\
\text { - Violation of places with } \\
\text { cultural value } \\
\text { - Violation of people's } \\
\text { rights }\end{array}$ & $\begin{array}{l}\text { - Deforestation, degradation of } \\
\text { natural forests and destruction of } \\
\text { communities' forest plantations } \\
\text { - Contamination of flora and fauna } \\
\text { - Contamination of rivers and ponds } \\
\text { (no water hydrocarbon parameter } \\
\text { in Peru) and disappearance of fish } \\
\text { - Aitr contamination } \\
\text { - Soil and subsoil contamination } \\
\text { - Engine and machinery noise } \\
\text { causing exit of wild animals and } \\
\text { decrease in number of species } \\
\text { - Process waters around wells abd } \\
\text { stagnant waters around old or } \\
\text { existing pipes overflowing during } \\
\text { rainy season }\end{array}$ \\
\hline
\end{tabular}

Source: Atalaya Workshop on Indigenous Peoples and Hydrocarbons. 2006. ORAU

\footnotetext{
${ }^{10}$ This include provisions contained in Legislative Decree $\mathrm{N}^{\mathrm{o}} 613$ of the Environmental and Natural Resources Code, Legislative Decree 757, and the Basic Law on Hydrocarbons (Law No 26221).
} 
Table 12: Positive and Negative Impacts of hydrocarbon projects on native communities according to the data collected by the Ombudsman's Office

\begin{tabular}{|l|l|}
\hline \multicolumn{1}{|c|}{ Positive Impacts } & \multicolumn{1}{c|}{ Negative Impacts } \\
\hline - Roads and highways & - Loss or impoverishment of resources required for \\
- Electric power distribution & - Bibsistence of the population, such as soil, water \\
- Job creation & - Loss of productive capacity \\
- Boost of the local market of goods and services & - Alterations in the landscape \\
required by the company and their contractors & - Impacts on the social identity and structure \\
- Oil revenues, excess revenues and royalties for & - Changes in cultural patterns, changes in ways to use \\
local and regional governments located in the & resources and use the space \\
area of influence &
\end{tabular}

Source: Ombudsman's Office 2007

Leaders of the Puntijao Native Community - Cohengua Sector, Ucayali River reported that fish taken from ponds and the river are no longer fit for human consumption, especially the "boquichico" (Semaprochilodus insignis) and carachama (Lyposarcus sp.), since they smell as gas for domestic use. Eating these fish result headaches, vomits and other disturbances. In 2007 people from the Inuya Valle also reported this type of contamination, but were unable to explain their causes because there are no oil or gas company performing any work in this area (Velasquez 2007).

Local people mix actual impacts with perceived or possible impacts. A clear distinction of the responsibility for environmental liability is not always made. People do not have enough technical assistance and sometimes rely on external funding for mobilizations (Ombudsman's Office 2007)

\section{Energy Development and Forests}

Some 68 million hectares of natural forests in Peru are subject to continuous deforestation at an annual rate of 250,000 to 300,000 hectares. Estimates are that about 8 million hectares have been deforested to date. Efforts being made to change this situation include the country's National Reforestation Plan (2005), with goals of establishing by 2024 forest plantations for industrial purposes covering 864,500 hectares (68\% located in the Amazon). The National Forest Project Portfolio for the Clean Development Mechanism (CDM) includes 11 projects in six regions of the country, totaling 67,394 hectares with an investment of US\$ 52.58 millions (Justo 2007).

Deforestation affects $9 \%$ of the 10.4 million hectares of forests in Ucayali. The situation is worse than in Loreto and Madre de Dios regions altogether (Vilchez 2007a). Deforestation results from both shifting cultivation and road opening for logging, which enables the arrival of farmers. Problems caused by deforestation need to include air pollution due to smoke from forest fires and from the burning of sawmill residues. Studies have shown that dust and sawdust particles in downtown Pucallpa reached a concentration of $546,64 \mathrm{ug} / \mathrm{m}^{3}$, a figure $500 \%$ greater than the allowed air quality standards (Yomona 2008).

Loss of natural forests worldwide contributes more to annual global emissions than the transportation sector. According to the 2000 greenhouse gases (GHGs) emissions in Peru were due to land use and land use change (47\%), energy (21\%), agriculture $(19 \%)$, industrial processes $(7 \%)$ and wastes $(6 \%)$ (Alvarez 2007). Forest or firewood burning produce emissions of trace $\left(\mathrm{CH}_{4}\right.$ and $\left.\mathrm{N}_{2} \mathrm{O}\right)$ at the time of combustion. According to the national inventory of dioxin and furan production, forest burning contributes with $21 \%$ and the incineration of wood and biomass residues contribute with $3 \%$ of their emissions (Calvo 2007).

Scientists anticipate that Amazon's annual average temperature may rise by three to seven degrees Celsius before 2100. In addition, significant decreases in rain may put regional biodiversity at risk and jeopardize the lifestyle and culture of the population that rely on forest products. Therefore, awareness is need that current deforestation rates may dramatically degrade Amazon forests in just a few decades, contributing thereby to global warming (Pucallpa Declaration on Climate Change and Southwest Amazonia 2007).

Possible effects of climate change in forests wither related to lower humidity Stern (2007) which in turn 
would increase likelihood of forest fires in the Amazon. Deforestation and fire contribute to increased $\mathrm{CO}_{2}$ emissions and consequently to decrease in humidity, which in turn increase the probability of forest fires. Everything would indicate that global warming will provoke a savannization process in the Amazon (Valverde \& Marengo 2007). Up to 20\% of the Amazon forest may be lost, with a $43 \%$ loss of its species.

Preventive measures for climate change thus include the reduction of deforestation in the Amazon and reduction of GHG emissions (Valverde \& Marengo 2007). Reducing deforestation is a highly efficient method to reduce emissions, and large international pilot programs are likely to very soon to explore the best alternatives to achieve that goal (Stern 2007). To mitigate climate change-related problems Valverde \& Marengo (2007) recommend: i) use of alternative forms of energy that do not involve fossil fuels; ii) tax carbon emissions in the energy sector $\left(\$ 50 /\right.$ ton $\left.\mathrm{CO}_{2}\right)$; iii) use of (solar and wind) renewable energies; iv) sustainable development, and v) lifestyle changes.

On November 3, 2007 the German Social and Technical Cooperation Service (DED) held the I International Congress on wood/biomass residues in which it was announced the potential of the Ucayali Region for the production of pellets, briquettes and charcoal from wood residues. It was mentioned the feasible implementation thereof due to its appropriate technology, relatively low cost, and Europe's high demand for these products. Atechnology to produce electric energy using forest residues was also announced. However, concerns remain about smoke and emission of gases resulting from this manufacturing process. To that effect, the Russian technical cooperation has expressed interest in carrying out a definitive study to industrialize sawdust and solid wastes produced in the district of Manantay and to produce methane (Zambrano 2008b).

\section{Energy Development and Indigenous Peoples}

For the General Office for Social Management of the MINEM, the promotion of harmonious relations between companies and local peoples is important. The application of participatory and socially responsible policies should occur within a sustainable development framework. However, there is still much to improve in the efficiency of the State's social and environmental management. Gretar efficiency would be obtained, for instance, by strengthening the bodies responsible for social impact assessment, the establishment of formal mechanisms for claims easily accessible to the population, and the strengthening of state bodies in charge of social, environmental and health care assessment and monitoring, as stated by the Ombudsman's Office. The creation of the Conflict Prevention Unit of the Presidency of the Cabinet Council is the first step for the State to have timely responsiveness in these matters.

The Ombudsman's Office also points out that the MINEM has recently made amendments to environmental regulations for mineral exploration in order to reduce the time for administrative procedures, even though that resulted in shorter periods for community participation and reduced community functions in the environmental assessment.

With the Energy and Mining policy basically geared to encourage private investment's contribution to the country's economy, the government in effect did not mind favoring oil and gas exploration and production rather than local communities' rights or biodiversity conservation. For instance, when overlaying on protected areas (such as El Sira Community Reservation in Ucayali) the MINEM and Peru Petro S.A. have violated the constitution as the State is bound to biodiversity conservation on Protected Natural Areas (PNA) (Gamboa 2007). This is a recurrent pattern in the country: as of 2007, 64\% of state-owned PNAs were given in concession to private companies for extraction industries (Alza \& Ipenza 2007). Gamboa (2008) states that 8 blocks in the Ucayali basin are overlaid on several communities, two Territorial Reservations and 5 PNAs. In March 2007, the Government amended the Law on Protected Natural Areas and revoked provisions considering Municipal Conservation Areas as protected natural areas included in the National System of Protected Natural Areas (SINANPE, in Spanish). This measure increased conflict and informality in these areas as there is no regulation and clearlydefined procedures (IWGIA 2008). Table 13 lists extraction companies in the Ucayali Region and their relation to local communities. 
Table 13: Extractive Companies and Superposition on Indigenous Territories in the Ucayali Basin

\begin{tabular}{|c|c|c|c|}
\hline Company & Block Number & Status & $\begin{array}{l}\text { Indigenous Presence / Protected } \\
\text { Natural Areas }\end{array}$ \\
\hline $\begin{array}{l}\text { The Maple Gas } \\
\text { Corporation }\end{array}$ & 31-B (Maquia) & Development & N/A \\
\hline $\begin{array}{l}\text { The Maple Gas } \\
\text { Corporation }\end{array}$ & $31-\mathrm{C}$ & Development & N/A \\
\hline \multirow[t]{2}{*}{$\begin{array}{l}\text { The Maple Gas } \\
\text { Corporation }\end{array}$} & $\begin{array}{l}\text { 31-D (Aguas } \\
\text { Calientes) }\end{array}$ & Development & N/A \\
\hline & $\begin{array}{l}\text { 31-E (Coronel } \\
\text { Portillo) }\end{array}$ & Development & N/A \\
\hline Repsol & 34 & & $\mathrm{~N} / \mathrm{A}$ \\
\hline Repsol & 35 & & Territories of the Murunahuas \\
\hline Repsol & $\begin{array}{l}57 \text { (Atalaya- } \\
\text { Sepahua) }\end{array}$ & $\begin{array}{l}\text { Exploration (since } \\
01 / 27 / 04)\end{array}$ & $\begin{array}{l}\text { Communities } \\
\text { Displacement area of Kugapakori, } \\
\text { Nahua and Kirineri peoples (between } \\
\text { Cusco and Ucayali) }\end{array}$ \\
\hline Repsol & $\begin{array}{l}90 \text { (Atalaya- } \\
\text { Raymondi) }\end{array}$ & $\begin{array}{l}\text { Exploration (since } \\
12 / 10 / 03 \text { ) }\end{array}$ & Communities \\
\hline $\begin{array}{l}\text { Petrolifera Petroleum del } \\
\text { Perú S.A.C. }\end{array}$ & 107 & $\begin{array}{l}\text { Exploration (since } \\
01 / 09 / 05) \text {. }\end{array}$ & $\begin{array}{l}\text { Communities, Cacataibo Indians living } \\
\text { in isolation } \\
\text { Community Reservation Yánesha } \\
\text { (1988) } \\
\text { / B. P. San Matías San Carlos (1987) }\end{array}$ \\
\hline Pluspetrol & 108 & $\begin{array}{l}\text { Exploration (since } \\
12 / 13 / 00)\end{array}$ & $\begin{array}{l}\text { Community Reservation Ashaninca } \\
\text { (2003) } \\
\text { / B. P. San Matías San Carlos (1987) }\end{array}$ \\
\hline Petrobras & 110 & $\begin{array}{l}\text { Exploration (since } \\
12 / 13 / 05 \text { ) }\end{array}$ & $\begin{array}{l}\text { Communities, Territorial Reservation } \\
\text { Murunahua }\end{array}$ \\
\hline $\begin{array}{l}\text { Pan Andean Resources } \\
\text { Plc }\end{array}$ & 114 & Exploration & $\begin{array}{l}\text { Communities } \\
\text { Community Reservation El Sira }\end{array}$ \\
\hline Amerada Hess & 118 & Exploration & $\mathrm{N} / \mathrm{A}$ \\
\hline Amerada Hess & $\begin{array}{l}119 \text { (Coronel } \\
\text { Portillo) }\end{array}$ & Exploration & $\mathrm{N} / \mathrm{A}$ \\
\hline Amerada Hess & $\begin{array}{l}120 \text { (Coronel } \\
\text { Portillo }\end{array}$ & Exploration & Communities \\
\hline $\begin{array}{l}\text { True Energy Perú S.A.C. } \\
\text { North American } \\
\text { Vanadium Perú S.A.C }\end{array}$ & 126 & $\begin{array}{l}\text { License for } \\
\text { exploration and } \\
\text { development }\end{array}$ & $\mathrm{N} / \mathrm{A}$ \\
\hline $\begin{array}{l}\text { Pan Andean Resources } \\
\text { Plc }\end{array}$ & 131 & $\begin{array}{l}\text { License Agreements } \\
\text { for Exploration and } \\
\text { Development of } \\
\text { Hydrocarbons }\end{array}$ & $\begin{array}{l}\text { Community Reservation El Sira } \\
\text { (2001) }\end{array}$ \\
\hline \multirow{3}{*}{$\begin{array}{l}\text { Pacific Stratus Energy } \\
\text { S.A } \\
\text { Pacific Stratus Energy } \\
\text { S.A }\end{array}$} & 135 & \multirow[t]{3}{*}{ Under negotiation } & \multirow{3}{*}{$\begin{array}{l}\text { Superposed with the Territorial } \\
\text { Reservation in favor of "Isconahua" } \\
\text { indigenous peoples living in isolation } \\
\text { (recognized by Regional Directorial } \\
\text { Resolution N } N^{\circ} 201-98-C T A R U / D G R A \\
\text {-OAJ-T dated 06/11/1998) and the } \\
\text { "Sierra del Divisor" protected natural } \\
\text { area, Reserved Zone (recognized by } \\
\text { Ministerial Resolution N } N^{\circ} 283-2006- \\
\text { AG dated 04/05/2006, published on } \\
04 / 11 / 06 \text { ). }\end{array}$} \\
\hline & 137 & & \\
\hline & & & \\
\hline $\begin{array}{l}\text { Pacific Stratus Energy } \\
\text { S.A }\end{array}$ & 138 & License Agreements & $\begin{array}{l}\text { Territorial Reservation "Isconahua" } \\
\text { Reserved Zone "Sierra del Divisor" } \\
\text { (2006) }\end{array}$ \\
\hline
\end{tabular}

N/A: Information Not Available, which does not mean absence of communities.

SOURCES: Ombudsman's Office 2006; Gamboa 2008; MINEM. October 2007; Technical Unit of the Hydrocarbon Area of the Ucayali Regional Mining Bureau. September 2006. (SERVINDI 2007) 
The exploratory stage for hydrocarbons is the one with greatest risk of contact with and impact on indigenous peoples living in isolation. This is due to the high mobility of equipment used for seismic exploration introduced in forests, winch often reach river basins' upper portions. The Ombudsman's Office thus suggests MINEM to recommend oil companies operating in areas where indigenous peoples live in isolation and/or initial contact to limit their intrusion as much as possible, with utmost technical rigor and respect for the habitat of these peoples. Recommendations include the establishment of a buffer zone between the company's area of influence and native peoples' territory (Ombudsman's Office 2006).

Conversely, gas companies declare to contribute to social, economic and sustainable development programs through the implementation of productive farming projects (Macedo 2008a).

Openness to private investment to the detriment of community property is also expressed through easements. For example, the Law for Private Investment in the Development of Economic Activities on Lands of the National Territory and Communities (Law 26505) in its Article 7 sets out the binding nature upon mine owners to have prior agreements with landowners. This rule will be revoked when regulations of Legislative Decree 1064 are approved (legal regime for the utilization of farming lands) which prescribes that there will be no negotiation and the State is entitled to authorize the entry and decide how much the company must pay the communities for easements located in their territories (Yrigoyen 2008).

\subsection{Indigenous Perspective on Hydrocarbon Activities}

There is no single indigenous peoples' position towards oil activities. Some voices are against it (AIDESEP and its regional counterpart ORAU) while others are in favor (CONAP) ${ }^{11}$. PERU PETRO and CONAP signed an institutional cooperation agreement which in practice "carries out hydrocarbon activities in exchange of tasks specifically related to the defense and development of Amazon communities and peoples in the domain of sustainable development." On the other hand, ORAU states that a false organization betrays indigenous peoples (El Peruano, May 28, 2007, page 7). Negative approaches to oil activities are related to environmental damage and human rights' violation.

Indigenous peoples have taken a position of not letting oil, gas, mineral and logging companies enter their territories given impacts caused by oil activities. They want to assert their rights and are calling for indigenous people's unity, considering that this is not the type of development they want. However, this position is not absolute. In a consultation held in the Pisqui Basin in November 2007, two communities located inside the Block (Nuevo Eden del Pisqui) agreed with the presence of oil companies whereas the remaining eight communities were in disagreement (Sanchez ${ }^{12}$ 2007).

\subsection{Consultation and Community Participation}

Prior consultation processes with indigenous peoples that may be affected by mining or energy activities are governed by the Regulations for Consultation and Community Participation (Ministerial Resolution $\mathrm{N}^{\circ}$ 596-2002-EM/DM) through the Procedures for the Approval of Environmental Studies in the Energy and Mining Sector. However, indigenous peoples consider that the oil companies have not been consulting communities and do not coordinate properly with leaders of their communities.

Indigenous peoples argue that consultations are merely informative on already made State decisions furthering the exploration and development of hydrocarbons, even in areas comprising indigenous peoples living in voluntary isolation. In September 2007 the Cacataibos produced a statement against oil development in defense of their non-contacted brothers (Quispe 2007a). The chief of the Mariscal Cáceres community expresses her concern because agreement 169 was not honored. As the consultation should have been earlier, she says that people should bring this to the attention of the President of the Republic and the congressmen representing the region.

\footnotetext{
11 Two large organizations are considered in Peru as representatives of indigenous peoples in the Amazon, the Interethnic Association for the Development of the Peruvian Rainforest (AIDESEP, in Spanish) and Peruvian Confederation of Amazon's Indigenous Peoples (CONAP, in Spanish). AIDESEP has larger national coverage, and was established earlier than CONAP. The relationship between the organizations features frequent clashes.

${ }^{12}$ Sánchez, P. Reactions of native communities against oil companies. Pucallpa. ORAU. Personal communication.
} 
“...impact studies disregard the social and cultural issues, do not tell the truth, everything is in favor of the company, the communities are just listeners and not participant actors" (OIRA leader)

In this respect, Ucayali's Communication Network press release on June 27, 2008 states that PERU PETRO understands that community participation and consultation is "the exchange of information, disclosure of concerns, fears or damage of interests of people influenced by an hydrocarbon project before any action plan is undertaken or permitted, being carried out in good faith."

The right of consultation is not fully exercised in Peru, as mechanisms and principles set forth by Agreement 169 of the International Labor Organization (ILO) are not addressed. Yet, Peru's ratification of the Agreement through Legislative Resolution No. 26253 turns it as part of the country's policies. Typical forms of native communities' communication are also disregarded; the process is not prior and not even binding.

At the Workshop on Hydrocarbon Concession, Protected Natural Areas and Territorial Rights held by ORAU (2006a) in Pucallpa in October, 2006 many participants ignored the existence of oil blocks in their communities, the majority of who showed their disagreement with the State's autocratic decision to establish those blocks. It was acknowledged, however, that communities and federations have been already visited by the company and the State (PERUPETRO and MINEM) to be informed of activities the latter wants to perform. The communities are never asked whether they agree or disagree with such activities; they are neither warned about possible impacts, just informed of advantages. Now MINEM is introducing a bill about community's participation. Sometimes not even the Regional Bureau itself is aware because negotiations take place directly with the community through an official letter. Table 14 shows the problems of access to environmental information and community participation. Table 15 shows the difference between how participation takes place and how indigenous peoples would like it to be. Basically, it states that emphasis is placed on promoting compliance processes rather than enhancing consultation processes. This is called social license.

\section{Table 14: Problems in the Access to Environmental Information and Community Participation}

- Perceived as State's formal requirement for administrative procedures

- Community members are seen just as "guests"

- In the past PERU PETRO only notified communities granted with oil concessions. Attempts are being made to change this through the implementation of the Consultation and Community Participation Regulations.

- Use of native languages is disregarded

- Reduction of community participation period from 25 to 20 days to make observations (Supreme Decree 014-2007-EM)

- Failure to inform and provide reasons for the disregarding of observations or recommendations from community participatory mechanisms

- There are no plans to hold public consultations and/or environmental assessment workshops during mining exploratory stages

- Scarce dissemination (use of local newspapers not available to the communities)

- No community access to technical assistance

- Short time (40 days) to review large Evaluation Studies publicly available and to conduct a Hearing

Source: Ombudsman's Office 2007

There are claims by indigenous peoples that companies did not keep their promises (radiotelephony, medicines, cash, and construction of an emergency center, among others). They also consider that the real beneficiaries are foreigners and that the few natives who manage to get a job are underpaid; even native personnel sporadically working for the company are verbally and psychologically abused. They also mention that the physical examination is excessive. The development promoted by companies has nothing to do with indigenous perspectives and show no social solidarity or willingness to get involved in the 
development of areas where resources are extracted and environmental impacts are generated (ORAU 2006a). Additionally, they consider that biologists and geologists extract information from communities.

\begin{tabular}{|c|c|}
\hline \multicolumn{2}{|c|}{ Table 15: How was the consultation and how would you like it to be? } \\
\hline IT WAS & WOULD LIKE IT TO BE \\
\hline 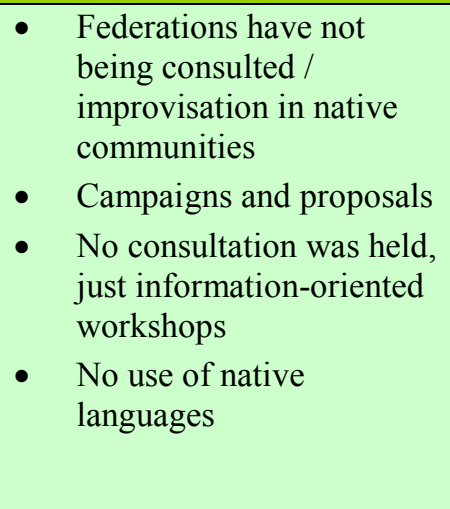 & $\begin{array}{l}\text { - Should last } 2 \text { - } 3 \text { days and have the presence of federations and } \\
\text { organizations (regional). } \\
\text { - } \text { Not only the pros, but also the cons of the oil activity should be } \\
\text { explained to the communities. } \\
\text { - } \text { Use of native languages } \\
\text { - } \text { Respect for indigenous peoples' rights } \\
\text { - Complete and not time-bounded information } \\
\text { - Surveillance and security should be provided } \\
\text { - State should arrange with the indigenous organizations so that } \\
\text { - } \text { these should inform their members. } \\
\text { Consultation must be prior to agreement and not afterwards }\end{array}$ \\
\hline
\end{tabular}

Source: ORAU. Atalaya Workshop on Indigenous Peoples and Hydrocarbons. 2006b.

According to AIDESEP, there are no technical conditions to begin gas explorations at reserves recently discovered in Block 57, between Sepahua, Cusco and Junin. AIDESEP regional vice-president gives as examples the cases of oil pipeline explosions and contamination of rivers. He argues that the Camisea Fund (FOCAM, in Spanish) does not benefit indigenous communities directly, and proposes that $5 \%$ of the gas revenues from Camisea be assigned directly to indigenous peoples (Vilchez 2008b).

\subsection{Energy Development and Indigenous Peoples in Voluntary Isolation}

Even the president of Peru is unaware of indigenous peoples living in voluntary isolation. In his controversial article "el Perro del Hortelano" (The Dog in the Manger), he says: "... the image of an "uncontacted" Amazon Indian has been created against the oil; that is to say, unknown but presumable, so millions of hectares should not be developed, and the Peruvian oil should remain underground while elsewhere it is paid US\$ 90 per barrel. To them, it is better that Peru continues importing and getting impoverished (Alan Garcia Perez, El Comercio, October 28, 2007). The chairman of PERU PETRO had previously denied on television the existence of uncontacted indigenous peoples (SERVINDI 2007b). Yet, the existence of indigenous peoples in voluntary isolation is fully acknowledged as stated in the Ombudsman's Report N 101 "Indigenous Peoples in Isolation and in Initial Contact ${ }^{13}$ "

In facing this situation, AIDESEP requires the following: i) unrestricted respect for pre-existing and acquired rights of the indigenous peoples in voluntary isolation in the Peruvian Amazon, ii) immediate complete exclusion of blocks overlaid on Territorial Reserves created and proposed for indigenous peoples living in isolation, since it endangers the life and health of these extremely vulnerable peoples, iii) final exclusion of oil blocks that are overlaid on territories of indigenous peoples living in voluntary isolation and which are in the exploratory and development stages (AIDESEP 2007). On December 13, 2007 the Federation of Cacataibo Indigenous Communities in Padre Abad (FENACOCA) declared itself to be against the seismic exploration of block 107, where 200 "non contacted" families live (Quispe 2007a).

AIDESEP's president explains that the indigenous organization had reached an agreement with MINEM and PERU PETRO through which the rights of indigenous peoples in voluntary isolation are respected. The indigenous leader remembered that on February 5, 2007 an agreement was reached regarding the Isconahua Territorial Reserves. Through that agreement, as soon as investors are interested in blocks subject to

13 Indigenous Peoples in Initial Contact are those who not long ago had been isolated and have recently established relations with the non-indigenous society, but wish to control and limit those relations (AIDESEP 2008). 
international auction (conducted by PERU PETRO), the company will report amendments to the block area in order to avoid overlays with territorial reserves officially declared by the State (SERVINDI 2007a).

\subsection{Indigenous Peoples and Biofuels}

The issue of biofuel crops in the Amazon is sensitive due its potential impacts to indigenous peoples. Single-crop farming may result in loss of biodiversity, agrochemical contamination and tends to promote private investments in areas eventually occupied by indigenous peoples. Although authorities in their discourse reaffirm using only degraded lands and having full respect for indigenous territories, the history of State-granted reforestation concessions in primary forests raises a red flag. AIDESEP expressed its rejection to the promotion of biofuels in Amazon's primary forests given their potential threat to indigenous peoples' livelihoods. It is worth mentioning that in October 2008 the Assembly of the International Union for Conservation of Nature (IUCN), regarded as the world's environmental assembly, recommended to the governments of the world to stop providing financial aid to biofuel production. In any event, decisions on the promotion of biofuel crops in indigenous territories must be made upon full consultation and participation of the indigenous peoples involved.

\section{Discussion}

Peru's sustainable development calls for energy policies consistent with the respect for native communities' rights and respect for environmental considerations. Within the Peruvian modernization process, private investments in the energy sector have received privileges and although the State emphatically mentions the redistribution of benefits derived from the exploration and development of non-renewable resources, the population's feeling is that in practice the State is more concerned about protecting companies' interests rather than those of the native communities. The recent package of laws enacted by the Executive due to the power granted by Congress to adequate the legal framework to regulations of the Free Trade Agreement with the United States has a clear orientation of disempowering native communities to further benefit private investments, mainly in agro-industry and biofuels. Although the Rainforest Law is in a strict sense idle in Congress, the same notions are in practice diluted in the above package of laws. The government considers that native communities' lands are not productive in hands of poor people with no financial means, technology or capacity to promote agro-industrial development. Social and environmental aspects are thus disregarded and presented as to restrain development (such as in the "Perro del hortelano" article).

When communities are able to assert their rights this is more the result of social pressures rather than clear respect for social and environmental policy. The State often appeals to the cheap tactic of discrediting the "progress antagonists" and regards them as backwards. But this is not only a matter of discourse; several rules have been issued which in practice criminalize protest. The direction given by the country's ruling party has thus changed from a more nationalist position during the previous administration to current position, more consistent with free trade. Although the Ombudsman's Office has reported this situation, subsequent measures indicate that this is just an attempt to give an environmental and social face to the energy policy which does not convince native peoples or the social or environmental leaders.

Not all companies favor exclusively environmental considerations. Issues such as corporate social responsibility, including environmental considerations, increasingly attract citizens' attention, whether due to external pressures or internal policies. Companies thus act based on what the State allows them to do, as an institutionality is required to enforce environmental and social standards.

While native people are required to keep on struggling to lawfully assert their legitimate rights, they should not only play a confrontational role, but also implement more direct strategies to help improving their negotiation abilities. They should, for example, learn to get to know how companies, or the State, think. This obviously calls for a strategy based on empathy and negotiation that has been elusive to all the players, each of them trying to impose their own arguments. Moreover, all burden attributable to extractive companies should be put into adequate contexts in order to distinguish degrees of responsibility. Some aspects attached to companies depend on indigenous communities' decision; other cases are of shared responsibilities, while still others are of direct degrees of guilt from companies. This is a precondition to enter into a constructive dialogue rather than the deaf dialogue that seems to be happening so far. 
The presence of extractive companies in native communities' territory is controversial not only among large indigenous organizations, but also within the communities themselves. Regional authorities often lose the perspective of the relevance of energy development and channel their actions to obtain greater benefit from oil companies, by using the argument of environmental pollution on native communities as a justification. Such argument, however, should be expressed through a comprehensive proposal for sustainable development connecting energy development, communities' wellbeing, and essential ecological processes. Communities also have mixed feelings in respect to extractive companies' supply of seasonal work, which is only partial. This offer turns out to be very attractive given labor constraints within communities. Yet, extractive companies cannot solve all social liabilities and the State should not neglect support to communities that eventually receive benefits from the exploration and development of extractive resources.

The issue of biofuels is also very controversial. Despite the fact that the use of "degraded" lands is not so reliable in Peru, it is possible to establish a participatory process relying not only on an ecologic and economic zoning, but also on the ecologic foundations of the Amazonian ecosystems as well. Landscape ecology foundations should be used to promote productive land use mosaics. For this purpose, it is critical that land registry and adjudication be continued, in a context of strict respect for indigenous territories.

Besides the key role to be played by the Ministry of Environment, the implementation of social control mechanisms is of paramount significance. Important activities to strengthen indigenous participation and social control can be derived from experiences in community environmental monitoring through overseeing structures connected to indigenous federations: monitoring impacts of activities carried out by hydrocarbon companies, and informing communities, companies and federations in case of incidents.

\section{Conclusions and Recommendations}

Taking into account the findings of this study the following can be concluded:

- A clear priority exists to favor private investments in the mining and hydrocarbon sectors over the indigenous peoples' rights. The package of laws dated June 2008 is aimed at clearing the "obstacles" to private investments and private property.

- There is political will to promote an environmental institutionality that overcomes structural deficiencies. How effective and how much real power will be granted to enforce the national and international environmental legislation remains to be seen. In order for that to be effective, organizational arrangements within the Ministry of the Environment need to be disclosed.

- Ucayali Region's energy policy is practically an extension of the national policy formulated by the Ministry of Energy and Mines. Despite the ongoing decentralization process, functions assigned to the Regional Bureau of Energy and Mines are limited by scarce financial and material support.

- Rather than an energy policy focused on sustainable development, the regional political agenda for energy development is closely oriented to increasing energy and excess revenues generated from hydrocarbon exploration and development within the regional territory.

- Oil exploration blocks are overlaid on native communities' territories, protected areas and territorial reservations for indigenous peoples in voluntary isolation, whether officially recognized or proposed by the indigenous organizations. The State remains firm in controlling the subsoil and in asserting its power to grant rights to the use of non-renewable natural resources.

- There are contradictions within the indigenous movement on accepting the presence of extractive companies in their territories. Despite the strong denial from their federations, some community members agree with such presence due to the generation of temporary labor opportunities.

- There is an overwhelming claim by communities on enhancing consultation and participatory mechanisms. Their perception is that greater emphasis has been placed on extracting information and conducting consultations to endorse concessions rather than seeking for consent or social license prior to the granting of oil or gas concessions. 
- The Regional Government of Ucayali has not taken any clear position regarding biofuel production, because deforestation may increase despite the priority given to the use of deforested areas.

- Some small private projects in Ucayali are being launched to further energy production from forest biomass, despite the fact that this alternative is not part of the Regional Government's policy.

Such conclusions define three priority recommendations for energy policy in the Ucayali Region of Peru:

- The Regional Government of Ucayali must promote the participatory formulation of an energy development policy in the context of sustainable development. In this regard, strict considerations of social and environmental respect need to be followed.

- The regional environmental management authority must be sufficiently autonomous, sound and transparent and have proper resources to carry out its functions effectively given the decentralization process, provided adequate coordination within different governmental levels.

- Community participation and social control mechanisms must be fostered in order to ensure that the implementation of non-renewable resources' exploration and development activities is carried out with proper management and safeguarding Amazon's essential ecologic processes.

\section{Revised Literature}

"AHORA", 2008. GOREU and PERU PETRO signed a Declaration on Strategic Alliance . Pucallpa, Peru. Wednesday, January 30, 2008. Page 4.

AIDESEP, 2008. Indigenous peoples in voluntary isolation, Indigenous peoples in initial contact. (online). Lima. Revised March 31, 2008. Available at:

http://www.aidesep.org.pe/index.php?id=20,157,0,0,1,0

Alza, Carlos and Cesar Ipenza. 2007. "Disjointed Governance: The case of environmental policy with regard to the distribution of hydrocarbon exploration in protected natural areas. APECO. Lima.

Banco Central de Reserva del Peru, 2006. Report 2006. Lima. P.144.

Bernales, Manuel. 2008. "Monitor environmental impacts on railroad track project between Brazil-Peru." In: Journal "La Region". Iquitos. Peru. Sunday, March 30, 2008. Page 13

Bernales, Antonio. 2007. Instruments that enable diagnose conflicts in extractive industries. Sustainable Future. Lima. March 22. Slides.

Calvo, Eduardo. 2007 Environmental impacts of biomass burning. IPCC. UNMSM. Lima. Slides.

CAMISEA, 2008. Camisea Project (Online). Available at: Revised March 31, 2008.

Campodonico, Humberto. 2007. Hydrocarbons and Mining income tax in selected Latin America countries. International Seminar: Natural Resources, Democracy and Development in Latin America. Grupo Propuesta Ciudadana. DESCO. Lima, December 5 and 6, 2007. Available at: http://www.4shared.com/dir/4950044 / 64bcd135/seminario_extractivas_2007.html

Coello, Javier. 2007. Perspective on development of biofuels in Peru. ITDG. II International Course: Clean Development Mechanism as a new business opportunity. Lima, July 11,12. Slides.

Electro Ucayali. 2008. Electricity in Ucayali (Online). Available at: $\mathrm{http} / / /$ www.electroucayali.com.pe/ElectroUcayali/infraestructura_generacion.aspx. Revised March 31,2008

Gamboa, César. 2008. Presentation of the Hydrocarbons activities in the Module of Training on Rights of Indigenous Peoples and Oil Activities. DAR. Senen Soi School. Pucallpa. Slides.

Gamboa, César. 2007. Legal Report: irregular superposition of hydrocarbon blocks within Protected Natural Areas and Territorial Reserves. DAR. Lima. 19 p. 
Gamio Aita, Pedro. 2007. Change of energy matrix and sustainable development. Objectives of state policy. Ministry of Energy and Mines. Lima. Slides.

GOREU, S / f. Concerted Regional Development Plan by GOREU 2004-2010. Pucallpa. 50 p.

Instituto del Bien Común. 2006. Atlas of Native Communities in the Central Jungle. Lima. 115 p.

IWGIA. 2008. The indigenous world 2008. Edition: Kathrin Wessendorf. Copenhagen. 608 p.

Justo, Julia. 2007. Progress of Clean Development Mechanism in Peru. National Environment Fund (FONAM). Lima. Slides.

Lanegra, Ivan. 2008. Myths that pollute. In: Sunday's supplement of "The Republic". Issue No. 503, Lima. Peru. Pp: 8-10.

Luna, Nelly. 2007. An environmental mess. In: El Comercio. Lima, Peru. June 10, 2007

Macedo, P. 2008. Gas, energy for agro regional. In Pucallpa's Journal “Ahora”, Peru. Saturday February 16 2008. Page 4.

Macedo, P. 2007a. 4,000 seedlings arrived for the company Etanol de Ucayaly Project: Journal "Ahora", Pucallpa, Peru. Friday November 23 2007. Page 6.

Macedo, P. 2007b. The company Etanol de Ucayali will sow 60 thousand hectares of sugar cane. In: Journal "Ahora", Pucallpa, Peru. March 22.

Ministry of Economy and Finance, 2007. Macroeconomic multi 2008-2010. Approved in the Council of Ministers meeting of May 30, 2007. Lima. 145 p.

Ministry of Energy and Mines, 2007a. Referential Energy Plan 2007-2016. (Online). Available at: http://www.minem.gob.pe/hidrocarburos/pub_planreferen_2006.asp. Accessed on 02 April 2008

Ministry of Energy and Mines. 2007b. National Energy Balance 2006. Office of Planning, Investment and International Cooperation. Lima. 199 p.

Ministry of Energy and Mines (MINEM) - Regional Government of Ucayali. 2007. Characterization of the Department of Ucayali, for Land Management. Pucallpa. 385 p.

Ministry of Energy and Mines (MINEM). 2004. Statistics. (Online). Available in http://www.minem.gob.pe/hidrocarburos/estad_inicio.asp. Revised February 12, 2008.

Monsalve, Claudia. 2005. Change of fuel under the CDM. Incorporating biofuels into the energy matrix of Peru. FONAM. Lima. Slides.

Museo de la Electricidad. 2008. Electricity in Peru. http://museoelectri.perucultural.org.pe/central2.htm. Revised March 31, 2008

Ombudsman's Office. 2007. Special Report: socio-environmental conflicts by mining activities in Peru. Version of April 16, 2007, which includes the notes presented to Congress on the same date. Lima. 99 p. Available at: http://www.defensoria.gob.pe/modules/Downloads/informes/extraordinarios/inf_extraordinario_04_0 7.pdf

Ombudsman's Office, 2006. Indigenous peoples in isolation and initial contact. Report No. 101. Lima. 107 p.

ORAU, $2006^{\text {a }}$. Workshop Oil Concessions, Protected Natural Areas and Territorial Rights. Pucallpa, from 23 to 25 October 2006. Memory. 19 p.

ORAU, 2005. Report on the case of Canaan de Cachiyacu and the oil company Maple Gas Corp. -ORAU's Technical Team, Robert Guimaraes, Ronald Suarez and Ximena Warnaars. 14 p.

ORAU 2006b. Workshop on Indigenous Peoples and Hydrocarbons, Atalaya. Memory. 7p.

Pucallpa's Declaration on Climate Changes and Southwest Amazonia, Pucallpa, Ucayali, Peru (Online). Available in http://map-amazonia.net/forum/showthread.php?t=274. Revised May 17, 2007

Pulgar-Vidal. Manuel. 2007. Environmental Governance. Resistance to use financial mechanisms and incentives Workshop of Environmental Analysis of Peru. Lima. Slides. 
Quispe. D. 2007a. Cacataibos defend territories of 200 families that were not contacted. In: Journal "Ahora", Pucallpa, Peru. December 13.

Quispe, D. 2007b. Deforested areas of the Amazon could be used for producing fuel. Alternatives to coca leaf production. In: Journal “Ahora”. Pucallpa, Peru. Wednesday, October 17, 2007

Quispe. D. 2007c. Cacataibos opposed to oil drilling. In defense of uncontacted brothers. In: Journal "Ahora", Pucallpa, Peru. September 7.

Rodriguez, Fernando. S / f. Deforestation and land degradation process in the Ucayali region. Foundation for a regional policy. Research Institute of the Peruvian Amazon. Pucallpa. Slides.

Salazar, Milagros. 2008. Myths that pollute. In: Sunday supplement of journal "La Republica". Issue No. 503, Lima. Peru. Pp: 8-10.Diapositivas.

Sanchez, Fernando. 2007. Panorama and public policies on biofuels in Latin America. CEPAL. COBER 2007. Lima 17 to May 19. Slides.

SERVINDI, 2007a. Denounce overlapping blocks of oil on protected areas and indigenous territories. February 1. Lima. Available at: http://www.servindi.org/archivo/2007/1603. Revised January 12, 2008

SERVINDI 2007b. Chairman of Peru Petro denies existence of uncontacted indigenous people. April 24. Lima. Available at: http://www.servindi.org/archivo/2007/861. Revised January 12, 2008.

SERVINDI, c. 2007 Peru: There will be no overlapping blocks of oil on protected reserves for isolated indigenous. April 10 2007. Available in http://www.servindi.org/archivo/2007/1904. Revised January 12,2008

Stern, N.H. 2007. The Stern report: the truth about climate change / Nicholas Stern [Translation Albino Santos (1st part) and Joan Vilaltella (2nd part)]. Barcelona: Paidós.

Tournon, J. 2002. The decline magic. Life and history of the Shipibo-Conibo of Ucayali. Amazon Center for Ecology and Practical Application (CAAAP). Lima. 450 p.

Ucayali Regional Director of Energy and Mines. 2007. Mining. Available in $\mathrm{http} / /$ www.regionucayali.gob.pe/eminas/index.php?option=com_content\&task=view\&id=43\&Itemid $=56$. Revidado on October 16, 2007.

UNDP, 2006. Peru Human Development Report 2006: Toward decentralization citizenship. Lima. 188p. p.

Valverde, M. and J. Marengo. 2007. The report of the Intergovernmental Panel on Climate Change: Key aspects of the report and its implications for the Amazon. CPTEC / INPE, São Paulo, Brazil. Slides.

Veen, Martijn. 2007. Baseline Biofuels in the Peruvian Amazon. Biofuels Workshop, November 8. Pucallpa. Slides

Velasquez, R. 2007. Claims that fish are contaminated. Leaders of Native Community of Puntijao. In: Journal “Ahora”. Pucallpa, Peru. Monday October 22

Vílchez, F. 2008th. Begin reforestation planting 3 thousand 700 hectares of oil palm. In: Journal "Ahora". Pucallpa, Peru. Wednesday January 30 2008. pp. 2.

Vílchez, F. 2008b. Proposed that 5\% of the oil revenues from Camisea gas be assigned to indigenous peoples to encourage work and balance pollution. In addition to a regional ordinance requiring reduce environmental impacts. In: Journal Now. Pucallpa, Peru. Friday January 18, 2008. pp. 2.

Vílchez, F. 2008c. Ministry of Energy and Mines proposed that Camisea gas pipeline will reach the Port of Pucallpa. In: Journal “Ahora”. Pucallpa, Peru. Thursday, January 17, 2008. pp. 2.

Vílchez, F. 2008d. The gas reserve in Sepahua is four times larger than the one in Aguaytía. In: Journal "Ahora". Pucallpa, Peru. Thursday January, 17, 2008. pp. 3.

Vílchez, F. 2007. Not yet enacted a legislation to maintain tax exemptions up to 2012. In: Journal "Ahora", Pucallpa, Peru. Saturday 22, December 2007. Page 2. 
Vílchez, F. 2007a. Deforestation affects 9\% of forests in Ucayali. In: Journal “Ahora”. Pucallpa, Peru. Friday, November 16, 2007 pp. 3.

Vílchez, F. 2007b. Indians refuse to accept exploration of Petro Peru's Block 120 by AMERADA. In: Journal "Ahora”. Pucallpa, Peru. Thursday March 22, 2007. Page 2.

WRM, 2008. Indigenous peoples and Biofuels. In: Bulletin 128 of the World Movement for the Tropical Forests. March 2008. Montevideo

Yomona, J. 2008. We breath particles exceeding by $500 \%$ that permitted by the air quality standards. In: Journal "Ahora". Pucallpa, Peru. Friday March 7, 2008. pp. 2.

Yrigoyen, Raquel. 2008. The contradictions of the law in Peru (IILS) / Cooperation - Action for Development. Cited in: Valuing our diversity. Supplement of El Comercio. August 10. Lima. 8p.

ORAU, 2006b. Taller de Hidrocarburos y Pueblos Indígenas. Atalaya. Memoria. 7p.

Zambrano, R. 2008a. Peruvian Congress approved the construction of a railroad track between Brazil and Peru. In: Journal “Ahora”. Pucallpa, Peru. Monday, March 24 2008. P. 2.

Zambrano, R. 2008b. Russians are interested in producing gas with sawdust and solid waste. In: Journal "Ahora". Pucallpa, Peru. Tuesday, March 4, 2008. pp. 2.

Zambrano, R. 2008c. Ucayali is prevented from receiving S/.44 million each year.for the Aguaytia Gas. In: Journal “Ahora”. Pucallpa, Peru. Tuesday, January 29 2008. pp. 2.

Zambrano, R. 2007a. GOREU develop a Bill project in order to obtain excess Revenues Resistance to use financial mechanisms and incentives from the Camisea Gas. Journal "Ahora". Pucallpa, Peru. Monday, 22 October 2007. pp. 2.

Zambrano, R. 2007b. Ucayali would receive \$ 21 million generated by the exploitation of the Aguaytía Gas. In: Journal "Ahora". Pucallpa, Peru. Friday, August 10, 2007. P. 2. 


\section{WORKING PAPERS IN THIS SERIES}

1. Agroforestry in the drylands of eastern Africa: a call to action

2. Biodiversity conservation through agroforestry: managing tree species diversity within a network of community-based, nongovernmental, governmental and research organizations in western Kenya.

3. Invasion of prosopis juliflora and local livelihoods: Case study from the Lake Baringo area of Kenya

4. Leadership for change in farmers organizations: Training report: Ridar Hotel, Kampala, 29th March to 2nd April 2005.

5. Domestication des espèces agroforestières au Sahel : situation actuelle et perspectives

6. Relevé des données de biodiversité ligneuse: Manuel du projet biodiversité des parcs agroforestiers au Sahel

7. Improved land management in the Lake Victoria Basin: TransVic Project's draft report.

8. Livelihood capital, strategies and outcomes in the Taita hills of Kenya

9. Les espèces ligneuses et leurs usages: Les préférences des paysans dans le Cercle de Ségou, au Mali

10. La biodiversité des espèces ligneuses: Diversité arborée et unités de gestion du terroir dans le Cercle de Ségou, au Mali

11. Bird diversity and land use on the slopes of Mt. Kilimanjaro and the adjacent plains, Tanzania

12. Water, women and local social organization in the Western Kenya Highlands

13. Highlights of ongoing research of the World Agroforestry Centre in Indonesia

14. Prospects of adoption of tree-based systems in a rural landscape and its likely impacts on carbon stocks and farmers' welfare: The FALLOW

Model Application in Muara Sungkai, Lampung, Sumatra, in a 'Clean Development

Mechanism' context

15. Equipping integrated natural resource managers for healthy Agroforestry landscapes.

17. Agro-biodiversity and CGIAR tree and forest science: approaches and examples from Sumatra.

18. Improving land management in eastern and southern Africa: A review of policies.

19. Farm and household economic study of Kecamatan Nanggung, Kabupaten Bogor, Indonesia: A socio-economic base line study of Agroforestry innovations and livelihood enhancement.

20. Lessons from eastern Africa's unsustainable charcoal business.

21. Evolution of RELMA's approaches to land management: Lessons from two decades of research and development in eastern and southern Africa

22. Participatory watershed management: Lessons from RELMA's work with farmers in eastern Africa.

23. Strengthening farmers' organizations: The experience of RELMA and ULAMP.

24. Promoting rainwater harvesting in eastern and southern Africa.

25. The role of livestock in integrated land management.

26. Status of carbon sequestration projects in Africa: Potential benefits and challenges to scaling up.

27. Social and Environmental Trade-Offs in Tree Species Selection: A Methodology for Identifying Niche Incompatibilities in Agroforestry [Appears as AHI Working Paper no. 9]

28. Managing tradeoffs in agroforestry: From conflict to collaboration in natural resource management. [Appears as AHI Working Paper no. 10]

29. Essai d'analyse de la prise en compte des systemes agroforestiers pa les legislations forestieres au Sahel: Cas du Burkina Faso, du Mali, du Niger et du Senegal.

30. Etat de la recherche agroforestière au Rwanda etude bibliographique, période 1987-2003

31. Science and technological innovations for improving soil fertility and management in Africa: A report for NEPAD's Science and Technology Forum.

32. Compensation and rewards for environmental services.

33. Latin American regional workshop report compensation.

34. Asia regional workshop on compensation ecosystem services.

35. Report of African regional workshop on compensation ecosystem services.

36. Exploring the inter-linkages among and between compensation and rewards for ecosystem services CRES and human well-being 
37. Criteria and indicators for environmental service compensation and reward mechanisms: realistic, voluntary, conditional and pro-poor

38. The conditions for effective mechanisms of compensation and rewards for environmental services.

39. Organization and governance for fostering Pro-Poor Compensation for Environmental Services.

40. How important are different types of compensation and reward mechanisms shaping poverty and ecosystem services across Africa, Asia \& Latin America over the Next two decades?

41. Risk mitigation in contract farming: The case of poultry, cotton, woodfuel and cereals in East Africa.

42. The RELMA savings and credit experiences: Sowing the seed of sustainability

43. Yatich J., Policy and institutional context for NRM in Kenya: Challenges and opportunities for Landcare.

44. Nina-Nina Adoung Nasional di So! Field test of rapid land tenure assessment (RATA) in the Batang Toru Watershed, North Sumatera.

45. Is Hutan Tanaman Rakyat a new paradigm in community based tree planting in Indonesia?

46. Socio-Economic aspects of brackish water aquaculture (Tambak) production in Nanggroe Aceh Darrusalam.

47. Farmer livelihoods in the humid forest and moist savannah zones of Cameroon.

48. Domestication, genre et vulnérabilité : Participation des femmes, des Jeunes et des catégories les plus pauvres à la domestication des arbres agroforestiers au Cameroun.

49. Land tenure and management in the districts around Mt Elgon: An assessment presented to the Mt Elgon ecosystem conservation programme.

50. The production and marketing of leaf meal from fodder shrubs in Tanga, Tanzania: A pro-poor enterprise for improving livestock productivity.

51. Buyers Perspective on Environmental Services (ES) and Commoditization as an approach to liberate ES markets in the Philippines.

52. Towards Towards community-driven conservation in southwest China: Reconciling state and local perceptions.

53. Biofuels in China: An Analysis of the Opportunities and Challenges of Jatropha curcas in Southwest China.

54. Jatropha curcas biodiesel production in Kenya: Economics and potential value chain development for smallholder farmers

55. Livelihoods and Forest Resources in Aceh and Nias for a Sustainable Forest Resource Management and Economic Progress

56. Agroforestry on the interface of Orangutan Conservation and Sustainable Livelihoods in Batang Toru, North Sumatra.

57. Assessing Hydrological Situation of Kapuas Hulu Basin, Kapuas Hulu Regency, West Kalimantan.

58. Assessing the Hydrological Situation of Talau Watershed, Belu Regency, East Nusa Tenggara.

59. Kajian Kondisi Hidrologis DAS Talau, Kabupaten Belu, Nusa Tenggara Timur.

60. Kajian Kondisi Hidrologis DAS Kapuas Hulu, Kabupaten Kapuas Hulu, Kalimantan Barat.

61. Lessons learned from community capacity building activities to support agroforest as sustainable economic alternatives in Batang Toru orang utan habitat conservation program (Martini, Endri et al.)

62. Mainstreaming Climate Change in the Philippines.

63. A Conjoint Analysis of Farmer Preferences for Community Forestry Contracts in the Sumber Jaya Watershed, Indonesia.

64. The highlands: a shared water tower in a changing climate and changing Asia

65. Eco-Certification: Can It Deliver Conservation and Development in the Tropics.

66. Designing ecological and biodiversity sampling strategies. Towards mainstreaming climate change in grassland management.

67. Towards mainstreaming climate change in grassland management policies and practices on the Tibetan Plateau

68. An Assessment of the Potential for Carbon Finance in Rangelands

69 ECA Trade-offs Among Ecosystem Services in the Lake Victoria Basin. 
69. The last remnants of mega biodiversity in West Java and Banten: an in-depth exploration of RaTA (Rapid Land Tenure Assessment) in Mount Halimun-Salak National Park Indonesia

70. Le business plan d'une petite entreprise rurale de production et de commercialisation des plants des arbres locaux. Cas de quatre pépinières rurales au Cameroun.

71. Les unités de transformation des produits forestiers non ligneux alimentaires au Cameroun. Diagnostic technique et stratégie de développement Honoré Tabuna et Ingratia Kayitavu.

72. Les exportateurs camerounais de safou (Dacryodes edulis) sur le marché sous régional et international. Profil, fonctionnement et stratégies de développement.

73. Impact of the Southeast Asian Network for Agroforestry Education (SEANAFE) on agroforestry education capacity.

74. Setting landscape conservation targets and promoting them through compatible land use in the Philippines.

75. Review of methods for researching multistrata systems.

76. Study on economical viability of Jatropha curcas L. plantations in Northern Tanzania assessing farmers' prospects via cost-benefit analysis

77. Cooperation in Agroforestry between Ministry of Forestry of Indonesia and International Center for Research in Agroforestry

78. "China's bioenergy future. an analysis through the Lens if Yunnan Province

79. Land tenure and agricultural productivity in Africa: A comparative analysis of the economics literature and recent policy strategies and reforms

80. Boundary organizations, objects and agents: linking knowledge with action in agroforestry watersheds

81. Reducing emissions from deforestation and forest degradation (REDD) in Indonesia: options and challenges for fair and efficient payment distribution mechanisms

82. Mainstreaming climate change into agricultural education: challenges and perspectives

83. Challenging conventional mindsets and disconnects in conservation: the emerging role of eco-agriculture in Kenya's landscape mosaics

84. Lesson learned RATA garut dan bengkunat: suatu upaya membedah kebijakan pelepasan kawasan hutan dan redistribusi tanah bekas kawasan hutan

85. The emergence of forest land redistribution in Indonesia

86. Commercial opportunities for fruit in Malawi

87. Status of fruit production processing and marketing in Malawi

88. Fraud in tree science

89. Trees on farm: analysis of global extent and geographical patterns of agroforestry

90. The springs of Nyando: water, social organization and livelihoods in Western Kenya

91. Building cpacity toward region-wide curriculum and teaching materials development in agroforestry education in Southeast Asia

92. Overview of biomass energy technology in rural Yunnan (Chinese - English abstract)

93. A pro-growth pathway for reducing net GHG emissions in China

94. Analysis of local livelihoods from past to present in the central Kalimantan ExMega Rice Project area

95. Constraints and options to enhancing production of high quality feeds in dairy production in Kenya, Uganda and Rwanda

96. Agroforestry education in the Philippines: status report from the Southeast Asian Network for Agroforestry Education (SEANAFE)

2010

97. Economic viability of Jatropha curcas L. plantations in Northern Tanzania- assessing farmers' prospects via cost-benefit analysis.

98. Hot spot of emission and confusion: land tenure insecurity, contested policies and competing claims in the central Kalimantan Ex-Mega Rice Project area

99. Agroforestry competences and human resources needs in the Philippines

100. CES/COS/CIS paradigms for compensation and rewards to enhance environmental Services

101. Case study approach to region-wide curriculum and teaching materials development in agroforestry education in Southeast Asia

102. Stewardship agreement to reduce emissions from deforestation and degradation (REDD): Lubuk Beringin's Hutan Desa as the first village forest in Indonesia

103. Landscape dynamics over time and space from ecological perspective 
104. A performance-based reward for environmental services: an action research case of "RiverCare" in Way Besai sub-watersheds, Lampung, Indonesia

105. Smallholder voluntary carbon scheme: an experience from Nagari Paningahan, West Sumatra, Indonesia

106. Rapid Carbon Stock Appraisal (RACSA) in Kalahan, Nueva Vizcaya, Philippines

107. Tree domestication by ICRAF and partners in the Peruvian Amazon: lessons learned and future prospects in the domain of the Amazon Initiative eco-regional program

108. Memorias del Taller Nacional: "Iniciativas para Reducir la Deforestación en la region Andino - Amazónica", 09 de Abril del 2010. Proyecto REALU Peru

109. Percepciones sobre la Equidad y Eficiencia en la cadena de valor de REDD en Perú Reporte de Talleres en Ucayali, San Martín y Loreto, 2009. Proyecto REALU-Perú.

110. Reducción de emisiones de todos los Usos del Suelo. Reporte del Proyecto REALU Perú Fase 1

111. Programa Alternativas a la Tumba-y-Quema (ASB) en el Perú. Informe Resumen y Síntesis de la Fase II. 2da. versión revisada

112. Estudio de las cadenas de abastecimiento de germoplasma forestal en la amazonía Boliviana

113. Biodiesel in the Amazon

114. Estudio de mercado de semillas forestales en la amazonía Colombiana

115. Estudio de las cadenas de abastecimiento de germoplasma forestal en Ecuador

116. How can systems thinking, social capital and social network analysis help programs achieve impact at scale? 
The World Agroforestry Centre is an autonomous, non-profit research organization whose vision is a rural transformation in the developing world where smallholder households

strategically increase their use of trees in agricultural landscapes to improve their food security, nutrition, income, health, shelter, energy resources and environmental sustainability. The Centre generates science-base knowledge about the diverse role that trees play in agricultural landscapes, and uses its research to advance policies and practices that benefit the poor and the environment.

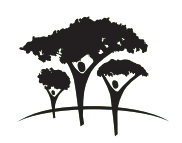

United Nations Avenue, Gigiri - PO Box 30677 - 00100 Nairobi, Kenya Tel: +254207224000 or via USA +16508336645

Fax: +254207224001 or via USA +1 6508336646 www.worldagroforestry.org 